\title{
East African pholcid spiders: an overview, with descriptions of eight new species (Araneae, Pholcidae)
}

\author{
Bernhard A. HUBER ${ }^{1, *}$ \& Charles M. WARUI ${ }^{2,3}$ \\ ${ }^{1}$ Alexander Koenig Research Museum of Zoology, Adenauerallee 160, 53113 Bonn, Germany. \\ ${ }^{*}$ Corresponding author, Email: b.huber@zfmk.de \\ ${ }^{2}$ Mount Kenya University, School of Pure \& Applied Sciences, P.O. Box 342-1000, Thika, Kenya. \\ Email: cwarui@mku.ac.ke; cmwarui@yahoo.com \\ ${ }^{3}$ National Museums of Kenya, Department of Zoology, P.O. Box 40658, 00100, Nairobi, Kenya. \\ ${ }^{1}$ urn:1sid:zoobank.org:author:33607F65-19BF-4DC9-94FD-4BB88CED455F \\ ${ }^{2,3}$ urn:Isid:zoobank.org:author:A8284950-EA33-411A-859D-22F3C690B64C
}

\section{Table of contents}

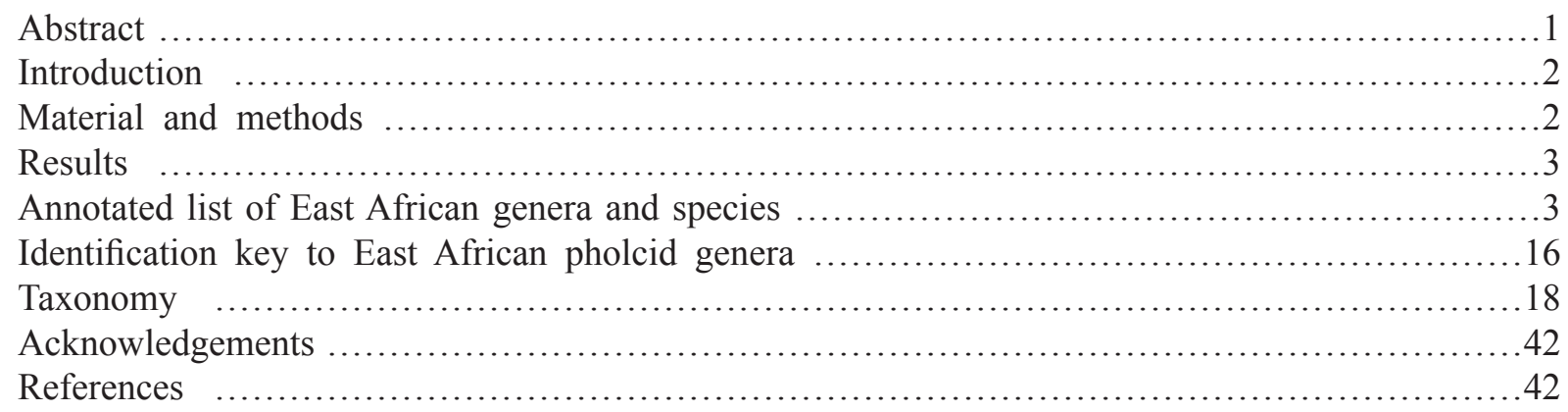

Abstract. This paper summarizes current knowledge about East African pholcids. East Africa is defined as the area from $12^{\circ} \mathrm{S}$ to $5^{\circ} \mathrm{N}$ and from $28^{\circ}$ to $42^{\circ} \mathrm{E}$, including all of Uganda, Kenya, Burundi, Rwanda, and Tanzania. An annotated list of the 15 genera and 87 species recorded from this area is given, together with distribution maps and an identification key to genera. Most East African species (90\%) belong to one of only six genera: Buitinga Huber, 2003 (21 species); Smeringopus Simon, 1890 (18); Pholcus Walckenaer, 1805 (17); Spermophora Hentz, 1841 (12); Leptopholcus Simon, 1893 (5) and Quamtana Huber, 2003 (4). Eight species for which DNA sequence data have been published recently are newly described: Buitinga batwa sp. nov., B. wataita sp. nov., Spermophora mau sp. nov., S. maathaiae sp. nov., S. bukusu sp. nov., S. kirinyaga sp. nov., S. kyambura sp. nov. and Quamtana nyahururu sp. nov. Crossopriza johncloudsleyi Deeleman-Reinhold \& van Harten, 2001, previously only known from Yemen, is redescribed based on specimens from Kenya. Additional new records are given for 21 previously described species.

Keywords. Pholcidae, East Africa, taxonomy, identification key.

Huber B.A. \& Warui C.M. 2012. East African pholcid spiders: an overview, with descriptions of eight new species (Araneae, Pholcidae). European Journal of Taxonomy 29: 1-44. http://dx.doi.org/10.5852/ejt.2012.29 


\section{Introduction}

The exploration of East African pholcid spiders started late and progress was slow for almost a century. Strand (1906a, 1906b, 1907, 1913) and Tullgren (1910) reported the first six species for the area considered here, and until the end of the $20^{\text {th }}$ century, the number increased to a mere 19 currently valid species. That this is in stark contrast to the actual diversity of the region was first demonstrated by a spider inventory made in the Tanzanian Uzungwa Mountains (Sørensen et al. 2002; Sørensen 2003). Pholcids were not only the most abundant spider family but proved to be represented in the area by a rich and highly endemic fauna. Most of this material and of other material available in collections has since been studied (Huber 2003a, 2007, 2009, 2011, 2012), and at the level of genera our knowledge about East African pholcids can probably be considered as fairly complete. At the level of species, the situation is very different. Several lines of evidence (unpublished material in collections; distribution patterns; poorly sampled areas; data from recent expeditions focusing on pholcids) indicate that many species remain undescribed and even more may remain undiscovered. The present paper is an attempt to summarize current knowledge about East African pholcids, complementing recent revisionary work that concentrated on major genera (Huber 2003a, 2011, 2012). Rather than closing the subject it is meant to facilitate access to the available information, to guide future collecting expeditions, and to point out some biologically interesting open questions.

\section{Material and methods}

A large part of the material studied herein was collected during recent expeditions to Kenya and Uganda (both in 2010). This material is deposited at Zoologisches Forschungsmuseum Alexander Koenig, Bonn (ZFMK) and National Museums of Kenya, Nairobi (NMKE). Further material was borrowed from the following institutions: Natural History Museum, London (NMH); California Academy of Sciences, San Francisco (CAS); Collection John and Frances Murphy, Middlesex, England (CJFM); Museum of Comparative Zoology, Cambridge (MCZ); Muséum national d'Histoire naturelle, Paris (MNHN); Musée royal de l'Afrique Centrale, Tervuren (MRAC); Netherlands Centre for Biodiversity Naturalis, Leiden (RMNH); Museo Zoologico de "la Specola", Firenze (MZF); Museum für Naturkunde, Berlin (ZMB); Zoological Museum, University of Copenhagen, Copenhagen (ZMUC).

Methods and terminology are as in recent revisions (Huber 2011, 2012). Measurements are in mm unless otherwise noted. Eye measurements are $+/-5 \mu \mathrm{m}$. Epigyna were cleared in a warm $\mathrm{NaOH}$ solution and stained with chlorazol black. Locality coordinates are in round brackets when copied from labels and original publications or when received directly from collectors, in square brackets when originating from some other source (such as online gazetteers, Google Earth, MRAC database, etc.). The following abbreviations are used: ALE: anterior lateral eyes; ALS: anterior lateral spinnerets; AME: anterior median eyes; a.s.l.: above sea level; L/d: length/diameter; PME: posterior median eyes.

The geographic area considered here is somewhat arbitrary, largely following a widely used definition of "East Africa" (e.g. Indeje et al. 2000; Shongwe et al. 2011) but adapted to include all of Kenya and all of Tanzania: the area from $12^{\circ} \mathrm{S}-5^{\circ} \mathrm{N}$ and $28^{\circ}-42^{\circ} \mathrm{E}$ (Fig. 16). The five countries completely included (Uganda, Kenya, Burundi, Rwanda, and Tanzania) form a political community (East African Community, EAC) rather than a natural or biologically defined unity. In fact, a recent analysis shows that East Africa presents a very complex biogeographical mixture and is best considered a large regional mosaic (Linder et al.2012). However, the area largely coincides with the distribution of the most diverse and only endemic pholcid genus in eastern Africa: Buitinga and its closest relatives currently assigned to Spermophora (the species around S. minotaura Berland, 1920 in Dimitrov, Astrin \& Huber 2012). 


\title{
Results
}

\author{
Class Arachnida Cuvier, 1812 \\ Order Araneae Clerck, 1757 \\ Family Pholcidae C.L. Koch, 1851
}

\section{Annotated list of East African genera and species}

Pholcidae described from East Africa as defined herein, with countries, references, and new records.

Anansus Huber, 2007

Anansus is widely distributed in tropical Africa (Huber 2007) but only two unidentified specimens (possibly representing one or two undescribed species) of these tiny spiders are known from East Africa (Fig. 16): $1 \overbrace{}^{\Uparrow}$ from Uganda, Budongo Forest near Sonso $\left(1.75^{\circ} \mathrm{N}, 31.58^{\circ} \mathrm{E}\right.$, in ZFMK Ar 5466) and 1 ㅇ from Uganda, Bwindi Impenetrable Forest National Park, Kitahurira $\left(0.97^{\circ} \mathrm{S}, 29.68^{\circ} \mathrm{E}\right.$, in CAS).

\section{Artema Walckenaer, 1837}

The natural distribution of Artema ranges from northern Africa to Central Asia. Only the synanthropic A. atlanta Walckenaer, 1837 has been collected in East Africa (Fig. 17).

1. Artema atlanta Walckenaer, 1837. Tanzania (Tullgren 1910), newly recorded for Kenya and Uganda.

\section{New records}

KENYA: Western Province: 2 우, in ZFMK (Ar 8660), Mbutali, in building ( $\left.0^{\circ} 29.3^{\prime} \mathrm{N}, 34^{\circ} 50.3^{\prime} \mathrm{E}\right)$, $1550 \mathrm{~m}$ a.s.l., 2 Feb. 2010 (B.A. Huber). Coast Province: 1 juv., in ZFMK (Ar 8661), Kwale, in building

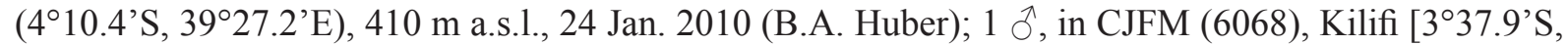
3950.9'E], garden scrub, 5 Sep. 1977 (Murphy). Rift Valley: $10^{\Uparrow}, 2$ q $9++$ juvs., in MCZ (34008),

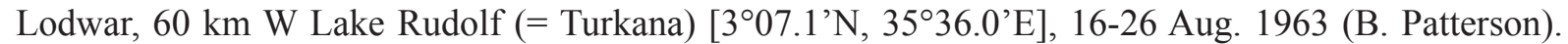
TANZANIA: Zanzibar, 2 ๙ $0^{\Uparrow}, 5$ 우 + juvs., in MCZ (34073), [ 6.2 $\left.{ }^{\circ} \mathrm{S}, 39.2^{\circ} \mathrm{E}\right], 18$ Sep. 1961 (E.D. Roper); $\widehat{\jmath}$, 우우 (2 vials), in MCZ (34075-76), May 1882 (C. Cooke). UGANDA: 1 으, in ZFMK (Ar 8662), Kasese District, Ruwenzori Mts., Nyakalengija, in building $\left(0^{\circ} 20.5^{\prime} \mathrm{N}, 30^{\circ} 02.6^{\prime} \mathrm{E}\right), 1590 \mathrm{~m}$ a.s.l., 1 Dec. 2010 (B.A. Huber). Additional new record. SOMALIA: 1 + , in MZF, Mogadishu [2 ${ }^{\circ} 02^{\prime} \mathrm{N}$, 45²1’E], 31 Mar.-14 Apr. 1924 (“Stef. + Pucc.”).

\section{Buitinga Huber, 2003}

Buitinga is a diverse genus endemic to East Africa (Fig. 18). Only B. mulanje Huber, 2003 (from Southern Malawi, see Huber 2003a) occurs outside the area considered here. The genus comprises mostly small, long-legged species that are largely restricted to well-preserved forests. The genus now includes 22 described species, but dozens of additional species are likely to occur (Huber 2003a).

2. Buitinga amani Huber, 2003. Tanzania (Huber 2003a).

\section{New records}

TANZANIA: 1 $\widehat{\partial}, 6$ 우 + juvs. in CAS, Tanga Region, East Usambara Mountains, $12 \mathrm{~km}$ SE Amani, Kihuhwi-Zigi Forest Reserve (506.3'S, 3840.6’E), 400-500 m a.s.1., 2-4 Nov.1995 (C. Griswold, N.

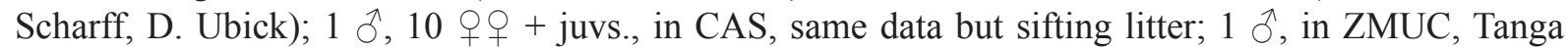
Region, Magrotto Hill [507’'S, 3846’E], Jul.-Sep.1994 (Frontier). 

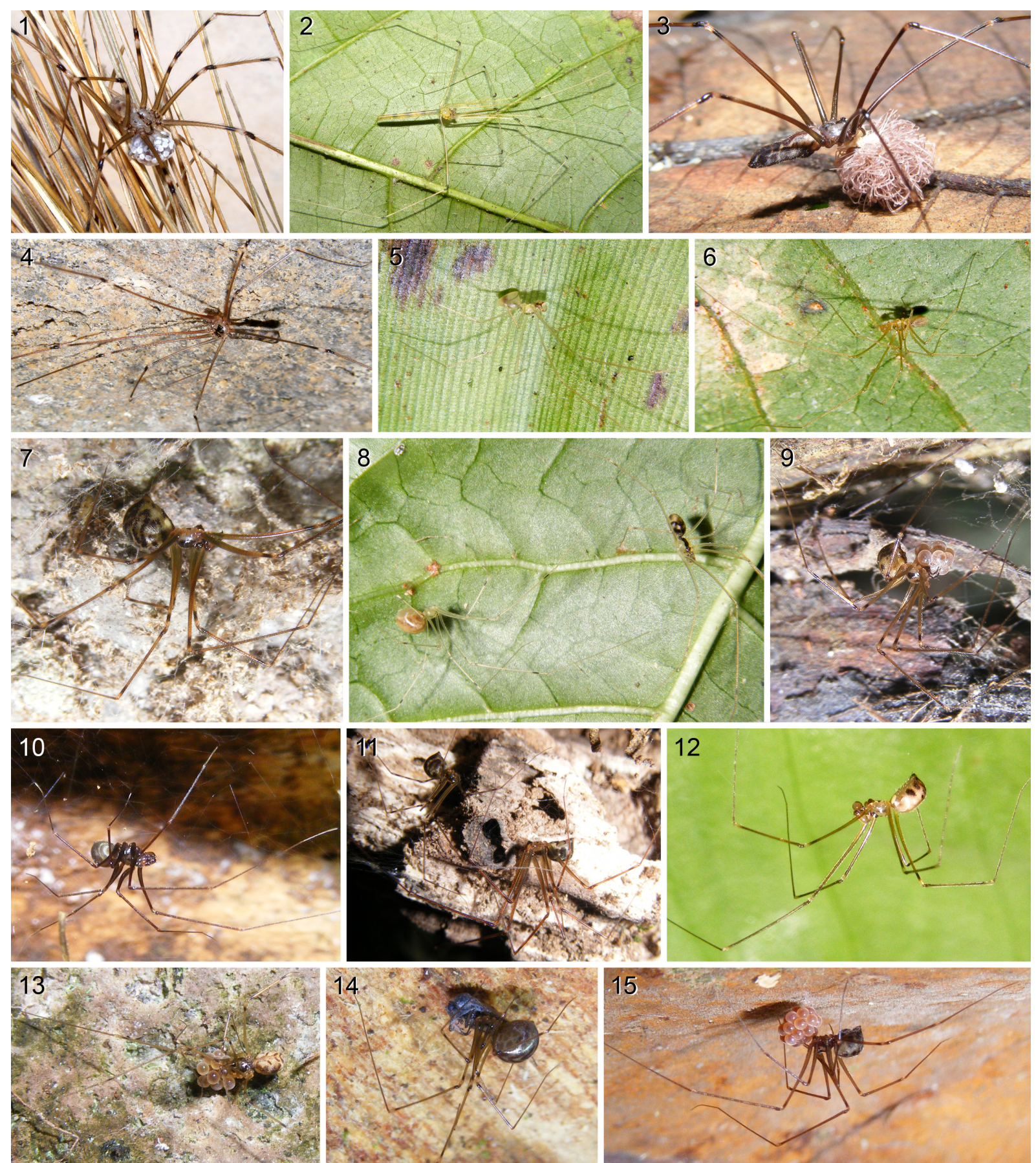

Figs 1-15. - 1. Artema atlanta Walckenaer, 1837 from Mbutali, Kenya. - 2. Leptopholcus tipula (Simon, 1907) from Semuliki, Uganda. - 3. Smeringopus mpanga Huber, 2012 from Kalinzu F.R., Uganda. - 4. Pholcus taita Huber, 2011 from Taita Mountains, Kenya. - 5. Quamtana kabale Huber, 2003 from Ruwenzori, Uganda. - 6. Quamtana nyahururu sp. nov. from Thompson Falls, Kenya. - 7-8. Spermophora minotaura Berland, 1920 from Mt. Kenya (7: dark morph; 8: light morph). 9. Spermophora mau sp. nov. from near Elburgon, Kenya. -10. Spermophora kirinyaga sp. nov. from Mt. Kenya, Kenya. - 11. Buitinga nigrescens (?) (Berland, 1920) from Ol Donyo Sabuk, Kenya. 12. Buitinga ruhiza Huber, 2003 from Buhoma, Uganda. - 13. Buitinga batwa sp. nov. from Mgahinga Gorilla N.P., Uganda. - 14. Buitinga ruwenzori Huber, 2003 from Ruwenzori, Uganda. - 15. Buitinga griswoldi Huber, 2003 from Buhoma, Uganda. Photos BAH. 
3. Buitinga asax Huber, 2003. Tanzania (Huber 2003a).

\section{New records}

TANZANIA: many $\widehat{\jmath} \widehat{\partial}$ and $q q$ (54 vials), in ZMUC, Iringa Region, Mufindi Distr., Uzungwa Scarp F.R., Kihanga Stream ( $8^{\circ} 22.1^{\prime}$ S, 35 58.7’E), 1800 m a.s.1., 17-27 May 1997 (ZMUC-SI expedition).

4. Buitinga batwa sp. nov. (see below). Uganda.

5. Buitinga buhoma Huber, 2003. Uganda (Huber 2003a).

\section{New records}

UGANDA: 4 ठึ $\widehat{0}, 6$ 우, in ZFMK (Ar 8663), Kanungu District, Bwindi Impenetrable N.P., waterfall trail near Buhoma $\left(0^{\circ} 59.8^{\prime}-1^{\circ} 00.2^{\prime} \mathrm{S}, 2^{\circ} 36.9-37.2^{\prime} \mathrm{E}\right), \sim 1500-1600 \mathrm{~m}$ a.s.1., 22 Nov. 2010 (B.A. Huber); 4 우 in pure ethanol, in ZFMK (Uga 124), same data. 2 ㅎํ, 2 우우, in ZFMK (Ar 8664), Bushenyi District, Kalinzu Forest Reserve $\left(0^{\circ} 22.5^{\prime}\right.$ S, $\left.30^{\circ} 06.9^{\prime} \mathrm{E}\right), 1500 \mathrm{~m}$ a.s.1., 28 Nov. 2010 (B.A. Huber); 1

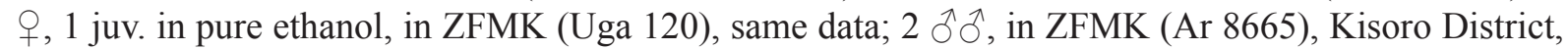
Mgahinga Gorilla N.P., at tree near park gate ( $1^{\circ} 21.2^{\prime}$ S, $29^{\circ} 37.1^{\prime}$ E), 2350 m a.s.1., 25 Nov. 2010 (B.A.

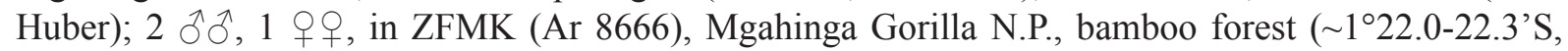
29³6.3-36.9’'E), 2500-2600 m a.s.1., 25 Nov. 2010 (B.A. Huber).

\section{Assigned tentatively}

UGANDA: $3 \widehat{\jmath} \widehat{\jmath}, 1$, in ZFMK (Ar 8667), Kisoro District, Mgahinga Gorilla N.P., bamboo forest ( $\left.1^{\circ} 22.0-22.3^{\prime} \mathrm{S}, 2^{\circ} 36.3-36.9^{\prime} \mathrm{E}\right), 2500-2600 \mathrm{~m}$ a.s.1., 25 Nov. 2010 (B.A. Huber); 2 우 in pure ethanol, in ZFMK (Uga 151), same data. 8 우 (2 vials), in ZFMK (Ar 8868-69), Kisoro District, between Nyakabande and Muko, roadside forest ( $1^{\circ} 15.2^{\prime}$ 'S, $\left.29^{\circ} 47.6^{\prime} \mathrm{E}\right), 2260 \mathrm{~m}$ a.s.1., 26 Nov. 2010 (B.A. Huber); 5 우 (2 vials) in pure ethanol, in ZFMK (Uga 130, 131), same data.

\section{Notes}

Some of the newly collected specimens above are assigned tentatively because they have a shorter abdomen and a slightly different color pattern. The MRAC has a very similar undescribed species from Burundi (Mt. Musumba), with slightly different procursus tip and longer proximal projections on the male chelicerae (MRAC 226400).

6. Buitinga ensifera (Tullgren, 1910). Tanzania (Tullgren 1910).

\section{Note}

No material of this species was available to Huber (2003a), and the type material seems to be lost. New material from Kenya ( $2 \hat{\jmath} \hat{\jmath}, 3$ 우 from Kirimeri Forest, near Runyenyere, near Mt. Kenya), in MRAC $(215277,293)$ might belong to this species but topotypical material (from Kilimanjaro) is needed to properly redescribe this species and to evaluate the Kenyan specimens.

7. Buitinga globosa (Tullgren, 1910). Tanzania (Tullgren 1910; Berland 1920; Huber 2003a sub Buitinga nigrescens).

\section{Note}

As indicated previously (Huber 2003a), this species might be a senior synonym of B. nigrescens (Berland, 1920). The first author has since seen what is left from Tullgren's (1910) syntypes (2 우 without abdomens, from Kilimanjaro, Kiboscho, in ZMB 9870; and 2 + + , 1 q without abdomen and a possibly male prosoma without chelicerae and palps from Kilimanjaro, Kibonoto, in MNHN, AR

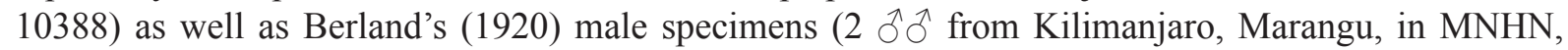
AR 10378). Berland's (1920) specimens seem to be correctly identified, and they correspond exactly to the specimens from Mt. Meru described as Buitinga nigrescens in Huber (2003a). The redescription of B. nigrescens in Huber (2003a) is thus probably based on a misidentification and refers to B. globosa. However, since no topotypical males are known of B. nigrescens (Mt. Kenya, "st. no. 39" at 2400 m a.s.l., now Naro Moru Track), and since newly collected males from other Kenyan localities (see 

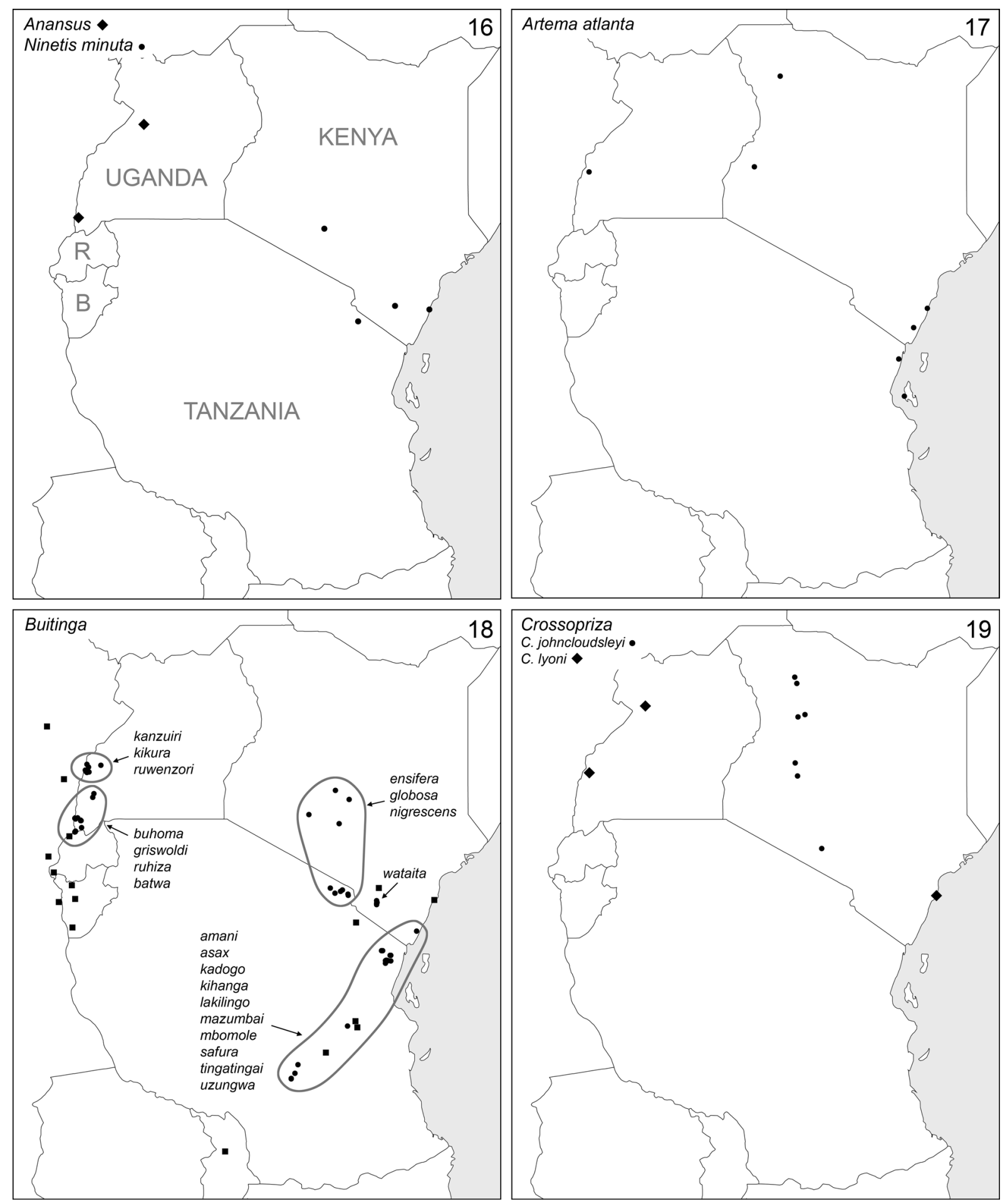

Figs 16-19. Known distributions of the genera Anansus, Ninetis, Artema, Buitinga, and Crossopriza in East Africa (R: Rwanda; B: Burundi). For detailed maps of Buitinga, see Huber (2003a). Squares: unidentified/undescribed specimens. 
B. nigrescens below) indicate that $B$. nigrescens might in fact be a valid species, the two species are not synonymized.

8. Buitinga griswoldi Huber, 2003. Uganda (Huber 2003a).

\section{New records}

UGANDA: 7 ๙ึ่, 2 우, in ZFMK (Ar 8670), Bushenyi District, Kalinzu Forest Reserve $\left(0^{\circ} 22.5^{\prime} \mathrm{S}\right.$, $30^{\circ} 06.9^{\prime} \mathrm{E}$ ), $1500 \mathrm{~m}$ a.s.1., 28 Nov. 2010 (B.A. Huber); 1 q in pure ethanol, in ZFMK (Uga 119), same data. 5 $\widehat{\jmath}, 2$ 2 , , in ZFMK (Ar 8671), Kanungu District, Bwindi Impenetrable N.P., waterfall trail near

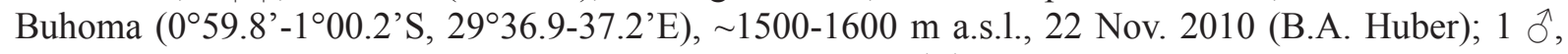
3 우우 in pure ethanol, in ZFMK (Uga 123), same data. 5 주, 2 우우, in ZFMK (Ar 8672), Bushenyi District, Kasyoha-Kitomi Forest Reserve ( $0^{\circ} 16.1^{\prime}$ 'S, 3009.1'E), 1280 m a.s.1., 29 Nov. 2010 (B.A. Huber); 4 우 in pure ethanol, in ZFMK (Uga 111), same data.

9. Buitinga kadogo Huber, 2003. Tanzania (Huber 2003a).

10. Buitinga kanzuiri Huber, 2003. Congo DR (Huber 2003a).

11. Buitinga kihanga Huber, 2003. Tanzania (Huber 2003a).

12. Buitinga kikura Huber, 2003. Congo DR (Huber 2003a).

13. Buitinga lakilingo Huber, 2003. Tanzania (Huber 2003a).

\section{New record}

TANZANIA: 6 ภ Lushoto Distr., Mazumbai Forest Reserve (449'S, 38²9’E), 1650-1730 m a.s.l., Jul. 1995 (ZMUC expedition).

14. Buitinga mazumbai Huber, 2003. Tanzania (Huber 2003a).

15. Buitinga mbomole Huber, 2003. Tanzania, Kenya (Huber 2003a).

16. Buitinga nigrescens (Berland, 1920). Kenya (Berland 1920).

\section{Note}

The Tanzanian specimens described as B. nigrescens in Huber (2003a) are very probably B. globosa (see above). Females of the two species appear indistinguishable, but newly collected males (and females) from Ol Donyo Sabuk National Park and Hell's Gate National Park (in ZFMK, Ar 8673-74, Ken 114) indicate that $B$. nigrescens might in fact be a valid species (with distinctively hooked bulbal apophysis). However, since no topotypical males are known of B. nigrescens (Mt. Kenya, Naro Moru Track), the identity of these newly collected specimens remains dubious.

17. Buitinga ruhiza Huber, 2003. Uganda (Huber 2003a).

\section{New records}

UGANDA: $4 \hat{\jmath}, 3$ 우 in ZFMK (Ar 8675), Kanungu District, Bwindi Impenetrable N.P., waterfall trail near Buhoma $\left(0^{\circ} 59.8^{\prime}-1^{\circ} 00.2^{\prime}\right.$ S, $\left.29^{\circ} 36.9-37.2^{\prime} \mathrm{E}\right), \sim 1500-1600 \mathrm{~m}$ a.s.1., 22 Nov. 2010 (B.A. Huber); 3 우, 1 juv. in pure ethanol in ZFMK (Uga 122), same data.

\section{Note}

The ZFMK has some poorly preserved specimens of a very similar undescribed species from Rwanda, near Nyakabuya, Cyamudongo Forest (ZFMK Ar 5210-12). The MRAC has specimens of a further undescribed species from Burundi, Forêt de Rwegura (2 $\widehat{\jmath}$ : MRAC 214019, 214108; 5 q $q$ : MRAC 213725, 214018, 214021, 214071, 214117). 
18. Buitinga ruwenzori Huber, 2003. Congo DR, Uganda (Huber 2003a).

\section{New records}

UGANDA: $2 \widehat{\jmath}, 22$ 우 in ZFMK (Ar 8876), Kasese District, Ruwenzori Mts., near Nyabitaba Hut $\left(\sim 0^{\circ} 21.5-21.8^{\prime} \mathrm{N}, 29^{\circ} 58.7-59.7^{\prime} \mathrm{E}\right), 2260-2600 \mathrm{~m}$ a.s.1., 1 Dec. 2010 (B.A. Huber); 1 § , 4 q $q, 4$ juvs. in pure ethanol, in ZFMK (Uga 156), same data. 1 o in ZFMK (Ar 8677), Ruwenzori Mts., between Nyabitaba Hut and Guy Yeoman Hut ( $\left.0^{\circ} 20.6-21.5^{\prime} \mathrm{N}, 2^{\circ} 55.6-58.7^{\prime} \mathrm{E}\right), 2660-3300 \mathrm{~m}$ a.s.1., 2 Dec. 2010 (B.A. Huber). 1 +, 1 juv. in ZFMK (Ar 8678), Ruwenzori Mts., between N.P. gate and Nyabitaba

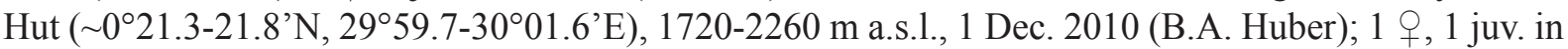
pure ethanol in ZFMK (Uga 159), same data. 1 ô, 1 ㅇ in ZFMK (Ar 8679), Kabarole District, Kibale Forest N.P., forest near Makerere Univ. Research Station $\left(0^{\circ} 33.2^{\prime} \mathrm{N}, 30^{\circ} 21.4^{\prime} \mathrm{E}\right), \sim 1500 \mathrm{~m}$ a.s.1., 6 Dec. 2010 (B.A. Huber).

19. Buitinga safura Huber, 2003. Tanzania (Huber 2003a).

\section{New records}

TANZANIA: 89 ô $\widehat{\partial}, 155$ 우 (191 vials, partly without date and altitude data) in ZMUC, Tanga Region, Lushoto Distr., Mazumbai Forest Reserve (449’S, 38²9'-30’E), 1370-1730 m a.s.1., Jul.-Dec. 1995

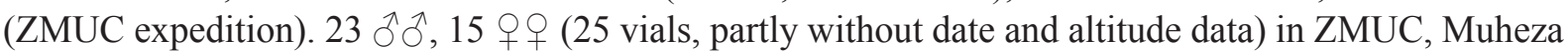

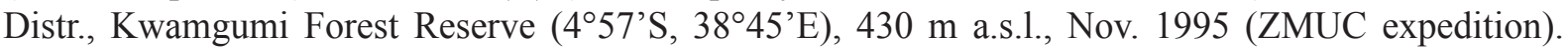

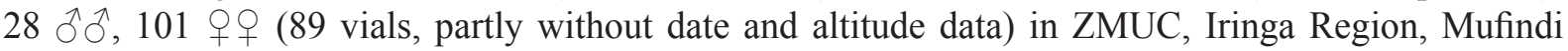
Distr., Uzungwa Scarp Forest Reserve (8³0'-32'S, 3552'E), 1370-1515 m a.s.1., Mar. 1995-Mar. 1996 (McKamey et al.); many $\widehat{\delta} \hat{\delta}$ and $q$ q $(80$ vials) in ZMUC, Uzungwa Scarp F.R., Kihanga Stream (8²2.1’S, 3558.7’E), $1800 \mathrm{~m}$ a.s.1., 17-27 May 1997 (ZMUC-SI expedition).

20. Buitinga tingatingai Huber, 2003. Tanzania (Huber 2003a).

\section{New records}

TANZANIA: Tanga Region: 9 के $\hat{\text {, }}, 7$ 우 (16 vials, partly without date and altitude data) in ZMUC,

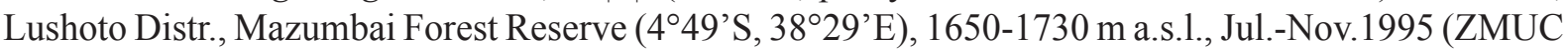
expedition); 3 우, 1 juv. in CAS, same data but 1400-1800 m a.s.1., 10-20 Nov. 1995 (Griswold, Scharff, Ubick).

21. Buitinga uzungwa Huber, 2003. Tanzania (Huber 2003a).

22. Buitinga wataita sp. nov. (see below). Kenya.

\section{Crossopriza Simon, 1893}

Apart from the pantropical synanthropic $C$. lyoni, only $C$. johncloudsleyi is here newly recorded from East Africa (Fig. 19).

23. Crossopriza johncloudsleyi Deeleman-Reinhold \& van Harten, 2001. Kenya (see below).

24. Crossopriza lyoni (Blackwall, 1867). Newly recorded for East Africa (Uganda, Kenya).

\section{New records}

UGANDA: Western Region: 1 in ZFMK (Ar 8680), Kasese District, Ruwenzori Mts., Nyakalengija, in building $\left(0^{\circ} 20.5^{\prime} \mathrm{N}, 30^{\circ} 02.6^{\prime} \mathrm{E}\right), 1590 \mathrm{~m}$ a.s.1., 1 Dec. 2010 (B.A. Huber). 1 \& in MRAC (125918), [Bulisa District], Murchison Falls [2 $\left.2^{\circ} 16.6^{\prime} \mathrm{N}, 31^{\circ} 41.1^{\prime} \mathrm{E}\right], 10$ Nov. 1963 (Cloudsley-Thompson). KENYA: Coast Province: 1 q in ZFMK (Ar 8681), Malindi, in hotel ( $\left.3^{\circ} 13.0^{\prime} \mathrm{S}, 40^{\circ} 07.8^{\prime} \mathrm{E}\right), 10 \mathrm{~m}$ a.s.1., 21 Jan. 2010 (B.A. Huber). 
Leptopholcus Simon, 1893

Of the ten species of Leptopholcus currently known from mainland Africa (Huber 2011), five occur in East Africa (Fig. 22).

25. Leptopholcus budongo Huber, 2011. Uganda, Kenya (Huber 2011).

26. Leptopholcus gracilis Berland, 1920. Kenya (Berland 1920; Brignoli 1980; Huber 2011), Tanzania, Somalia (Huber 2011).

27. Leptopholcus gurnahi Huber, 2011. Tanzania (Huber 2011).

28. Leptopholcus signifer Simon, 1893. Kenya (Huber 2011).

29. Leptopholcus tipula (Simon, 1907). Uganda (Huber 2011).

Micropholcus Deeleman-Reinhold \& Prinsen, 1987

Only the synanthropic M. fauroti (Simon, 1887) has been collected in East Africa (Huber 2011) (Fig. 21).

30. Micropholcus fauroti (Simon, 1887). Kenya (Deeleman-Reinhold \& Prinsen 1987; Huber 2011), Congo DR, Tanzania, Uganda, Somalia (Huber 2011).

Modisimus Simon, 1893

Modisimus is a New World genus; only the synanthropic M. culicinus (Simon, 1893) has a pantropical distribution. This tiny species is probably not rare, but it has previously been recorded only once from Africa (Congo DR; Lawrence 1938; sub Hedypsilus lawrencei). It is here newly recorded for East Africa (Fig. 20).

31. Modisimus culicinus (Simon, 1893). Newly recorded for East Africa (Kenya).

\section{New record}

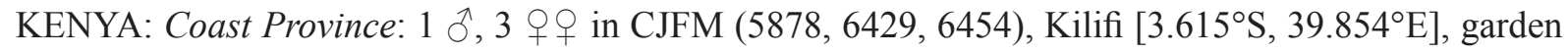
scrub, 30 Aug.-19 Sep.1977 (3 vials) (Murphy).

\section{Ninetis Simon, 1890}

Of the five species of Ninetis distributed from Namibia to Yemen, only N. minuta (Berland, 1919) has been collected in East Africa (Fig. 16).

32. Ninetis minuta (Berland, 1919). Kenya (Berland 1919; Huber 2000; Huber \& El Hennawy 2007), Tanzania (Huber 2000), Somalia (Huber \& El Hennawy, 2007).

\section{New record}

KENYA: Coast Province: $1 \widehat{\partial}, 5$ 우 in CJFM $(5952,6014,6123)$, Kilifi $\left[3.615^{\circ} \mathrm{S}, 39.854^{\circ} \mathrm{E}\right]$, coastal scrub, 1-6 Sep. 1977 (3 vials) (Murphy).

Pehrforsskalia Deeleman-Reinhold \& van Harten, 2001

Pehrforsskalia includes three described species, two of which occur in East Africa (Fig. 20): the widely distributed P. conopyga Deeleman-Reinhold \& van Harten, 2001 and P. shambaa Huber, 2011 from Tanzania. 
33. Pehrforsskalia conopyga Deeleman-Reinhold \& van Harten, 2001. Burundi, Uganda (Huber 2009); newly recorded for Kenya.

\section{New record}

KENYA: Rift Valley: 1 i in CAS, Marich Pass Field Studies Centre (1³2.2’S, 35²7.4'E), $3000 \mathrm{ft}$. a.s.l., 13 Jul. 1999 (W.J. Pulawski, J.S. Schweickert).

34. Pehrforsskalia shambaa Huber, 2011. Tanzania (Huber, 2011).

Pholcus Walckenaer, 1805

In East Africa, Pholcus is represented by 17 species from five species groups identified in Huber (2011). Two species groups are endemic to East Africa and restricted to the southeastern part of East Africa (Fig. 23): the lamperti group ( 8 species) and the taarab group (3 species); each of the other three groups ranges further west or north respectively and is in East Africa restricted to the northwestern part: the chappuisi group (4 species in East Africa), the bamboutos group (Ph. hoyo Huber, 2011), and the circularis group (Ph. leruthi Lessert, 1935).

35. Pholcus amani Huber, 2011. Tanzania (Huber 2011).

36. Pholcus chappuisi Fage, 1936. Kenya (Fage \& Simon 1936; Huber 2011).

37. Pholcus fagei Kratochvil, 1940. Kenya (Simon \& Fage 1922; Huber 2011).

38. Pholcus hoyo Huber, 2011. Congo DR (Huber 2011).

39. Pholcus kihansi Huber, 2011. Tanzania (Huber 2011).

40. Pholcus kwamgumi Huber, 2011. Tanzania, Kenya (Huber 2011).

41. Pholcus kyondo Huber, 2011. Congo DR (Huber 2011).

42. Pholcus lamperti Strand, 1907. Tanzania (Strand 1907; Simon \& Fage 1922; Huber 2011).

43. Pholcus leruthi Lessert, 1935. Rwanda, Uganda, Kenya (Huber 2011).

44. Pholcus lilangai Huber, 2011. Tanzania (Huber 2011).

45. Pholcus lupanga Huber, 2011. Tanzania (Huber 2011).

46. Pholcus mazumbai Huber, 2011. Tanzania (Huber 2011).

47. Pholcus strandi Caporiacco, 1941. Ethiopia (Caporiacco 1941).

48. Pholcus taarab Huber, 2011. Tanzania, Malawi (Huber 2011).

49. Pholcus taita Huber, 2011. Kenya (Huber 2011).

50. Pholcus twa Huber, 2011. Congo DR, Burundi, Rwanda, Uganda, Sudan (Huber 2011).

51. Pholcus wahehe Huber, 2011. Tanzania (Huber 2011).

Physocyclus Simon, 1893

Physocyclus is a New World genus. Only the pantropical synanthropic P. globosus (Taczanowski, 1874) has been collected in East Africa (Fig. 24).

52. Physocyclus globosus (Taczanowski, 1874). Tanzania (Saaristo, 2001); newly recorded for Burundi, Kenya, Malawi, and Uganda. 

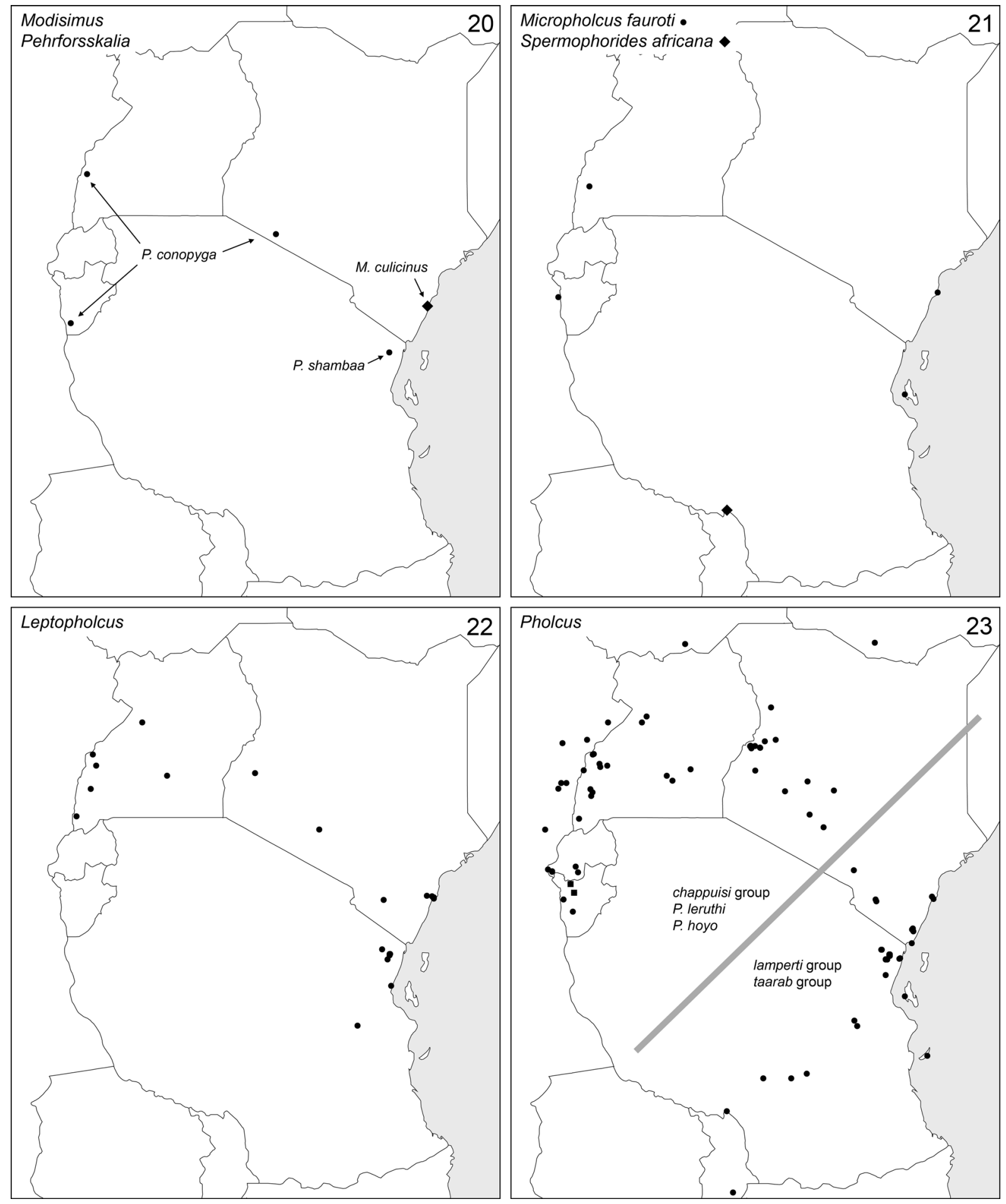

Figs 20-23. Known distributions of the genera Modisimus, Pehrforsskalia, Micropholcus, Spermophorides, Leptopholcus, and Pholcus in East Africa. For detailed maps of Leptopholcus and Pholcus, see Huber (2011). Squares: unidentified/undescribed specimens. 
New records

BURUNDI: 1 i in MRAC (134827), Bujumbura [3²2.2'S, 29²2.0'E], 2 Jan. 1969 (J. Lewalle). KENYA: $1 \partial^{\lambda}, 1$ juv. in ZMUC, Malindi, Silversand Campsite [ $3^{\circ} 14.0^{\prime}$ S, 40 ${ }^{\circ} 07.6^{\prime}$ 'E], 12 Aug. 1979 (N.

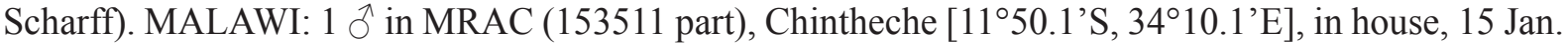
1978 (R. Jocqué). TANZANIA: 1 o in MRAC (125959), Zanzibar [ $6^{\circ} 10^{\prime}$ S, 39¹2’E], 26 Nov. 1968 (J. Cloudsley Thompson); 1 $\widehat{\jmath}, 1$ juv. in MRAC (159419), Dar es Salaam, U.D.S.M Campus [6 $6^{\circ} 46.8^{\prime}$ S, 39¹2.2'E], 1977 (K.M. Howell and zoology students); 5 juvs. in CAS, Dar es Salaam, in house, 25-

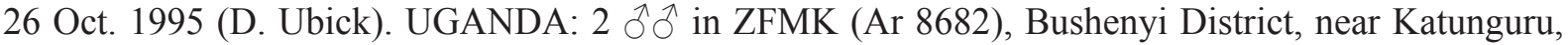
in building $\left(0^{\circ} 08.9^{\prime} \mathrm{S}, 30^{\circ} 03.9^{\prime} \mathrm{E}\right), 950 \mathrm{~m}$ a.s.1., 29 Nov. 2010 (B.A. Huber); 2 oे $^{\wedge}, 1$ ๆ in ZFMK (Ar 8683), Masindi District, Nybyeya, in building ( $\left.{ }^{\circ} 40.3^{\prime} \mathrm{N}, 31^{\circ} 32.2^{\prime} \mathrm{E}\right), 1145 \mathrm{~m}$ a.s.1., 9 Dec. 2010 (B.A. Huber).

Quamtana Huber, 2003

Quamtana is most diverse in southern Africa, but a few species occur as far north as Cameroon, Congo DR, Uganda (Huber 2003b), and Kenya (herein). Four species are currently known from East Africa (Fig. 25). The new species $Q$. nyahururu represents the first record of the genus for Kenya and Tanzania.

53. Quamtana biena Huber, 2003. Congo DR (Huber 2003b).

54. Quamtana kabale Huber, 2003. Uganda (Huber 2003b).

\section{New records}

UGANDA: 6 $\widehat{\jmath}, 6$ 우, 1 juv. in ZFMK (Ar 8684), Kasese District, Ruwenzori Mts., near N.P. gate $\left(\sim 0^{\circ} 21.3^{\prime} \mathrm{N}, 30^{\circ} 01.6^{\prime} \mathrm{E}\right), \sim 1800 \mathrm{~m}$ a.s.1., underside of leaves (mostly banana), 1 \& 3 Dec. 2010 (B.A. Huber); 1,, 6 우, 1 juv. in pure ethanol in ZFMK (Uga 141), same data.

55. Quamtana kitahurira Huber, 2003. Uganda (Huber 2003b); newly recorded for Burundi.

\section{New record}

BURUNDI: 1 in ZFMK (Ar 5265), Nyakabuya, Cyamudongo [2.868 $\left.\mathrm{S}, 29.503^{\circ} \mathrm{E}\right]$, Oct.1993 (T. Wagner).

56. Quamtana nyahururu sp. nov. (see below). Kenya, Tanzania.

Smeringopus Simon, 1890

With 55 species, Smeringopus is currently the most species-rich Afrotropical pholcid genus. Eighteen species in eight species groups have been described from East Africa (Huber 2012). Three species groups are endemic to East Africa: rubrotinctus group (5 species), chogoria group (2 species) and S. ngangao. The other five groups (arambourgi group; peregrinus group; roeweri group; S. pallidus (Blackwall, 1858); S. lesserti Kraus, 1957) are more widely distributed (Huber 2012) (Fig. 26).

57. Smeringopus bujongolo Huber, 2012. Uganda, Congo DR (Huber 2012).

58. Smeringopus butare Huber, 2012. Congo DR, Burundi, Rwanda (Huber 2012).

59. Smeringopus bwindi Huber, 2012. Congo DR, Uganda (Huber 2012).

60. Smeringopus carli Lessert, 1915. Uganda (Lessert 1915), Tanzania (Huber 2012).

61. Smeringopus chogoria Huber, 2012. Kenya (Huber 2012).

62. Smeringopus lesserti Kraus, 1957. Congo DR (Huber 2012).

63. Smeringopus lubondai Huber, 2012. Congo DR (Huber 2012).

64. Smeringopus mgahinga Huber, 2012. Congo DR, Uganda (Huber 2012). 

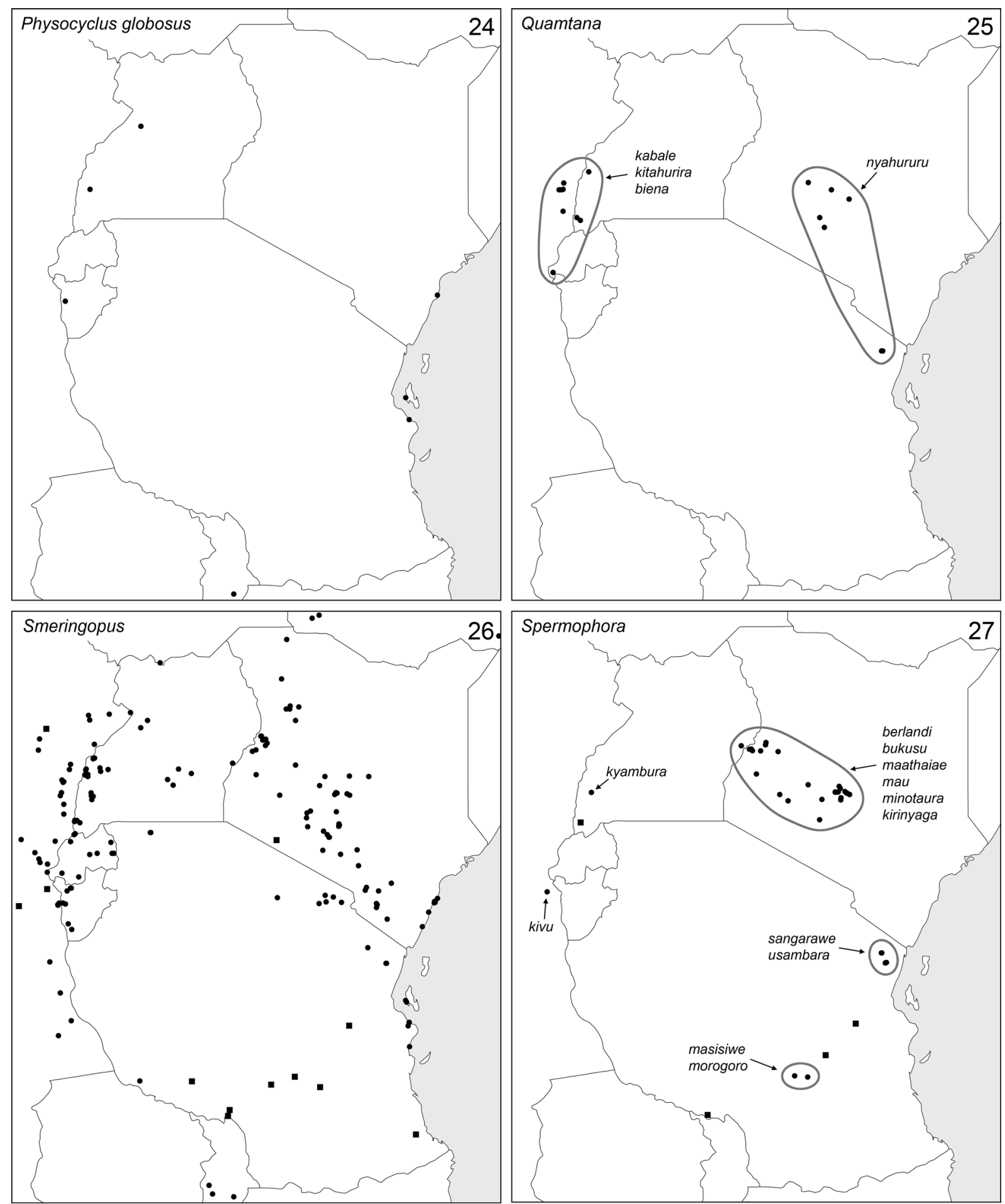

Figs 24-27. Known distributions of the genera Physocyclus, Quamtana, Smeringopus and Spermophora in East Africa. For detailed maps of Quamtana see Huber (2003b), of Smeringopus see Huber (2012) and of Spermophora see Huber (2003a). Squares: unidentified/undescribed specimens. 
65. Smeringopus mpanga Huber, 2012. Uganda (Huber 2012).

66. Smeringopus ngangao Huber, 2012. Kenya, Tanzania (Huber 2012).

67. Smeringopus pallidus (Blackwall, 1858). Burundi, Congo DR, Malawi, Tanzania, Uganda (Huber 2012).

68. Smeringopus peregrinoides Kraus, 1957. Rwanda, Tanzania (Kraus 1957; Huber 2012), Congo DR, Burundi, Uganda, Kenya (Huber 2012).

69. Smeringopus peregrinus Strand, 1906. Tanzania (Strand 1906b; Tullgren 1910; Huber 2012), Kenya, Uganda (Huber 2012).

70. Smeringopus roeweri Kraus, 1957. Rwanda (Kraus 1957), Congo DR, Malawi, Tanzania (Huber 2012).

71. Smeringopus rubrotinctus Strand, 1913. Rwanda (Strand 1913; Huber 2012), Burundi (Huber 2012).

72. Smeringopus ruhiza Huber, 2012. Burundi, Uganda (Huber 2012).

73. Smeringopus turkana Huber, 2012. Kenya, Ethiopia (Huber 2012).

74. Smeringopus zonatus Strand, 1906. Ethiopia (Strand 1906a).

Spermophora Hentz, 1841

Spermophora is in fact an Asian genus (Huber 2005) and African representatives have tentatively been assigned to it for lack of a better hypothesis (Huber 2003a). Recent molecular data (Dimitrov et al. 2012) suggest that at least the six Kenyan species (Fig. 27) are closely related to the East African genus Buitinga. Twelve East African species are currently assigned to Spermophora.

75. Spermophora berlandi Fage, 1936. Kenya (Fage \& Simon 1936).

76. Spermophora bukusu sp. nov. (see below). Kenya.

77. Spermophora kirinyaga sp. nov. (see below). Kenya.

78. Spermophora kivu Huber, 2003. Congo DR (Huber 2003a).

79. Spermophora kyambura sp. nov. (see below). Uganda.

80. Spermophora maathaiae sp. nov. (see below). Kenya.

81. Spermophora masisiwe Huber, 2003. Tanzania (Huber 2003a).

82. Spermophora mau sp. nov. (see below). Kenya.

83. Spermophora minotaura Berland, 1920. Kenya (Berland 1920; Simon \& Fage 1922; Huber 2003a).

Types

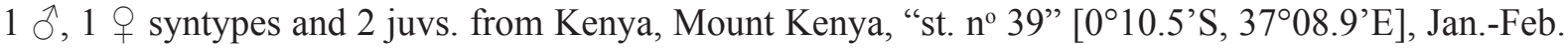
1912 (Alluaud, Jeannel), in MNHN (AR 10368), examined (not available in Huber 2003a).

\section{Note}

This species shows slight morphological variation (male cheliceral apophyses) and conspicuous color variation. The position of the frontal male cheliceral apophyses varies from almost parallel to strongly diverging. Huber (2003a) mentioned color variation with respect to the epigynum but it also occurs on carapace and abdomen in both males and females. Below, specimens are divided into three morphs: light morph (median dark band on carapace, light sternum, two large marks on abdomen or monochromous light abdomen; Figs 55, 56); medium morph (pair of narrow dark stripes on carapace do not reach lateral margins, dark sternum; abdomen pattern in principle as in dark morph but less developed), and dark 
morph (wide black stripes on carapace reaching lateral margins, dark sternum; complex dark pattern on abdomen; Figs 53, 54). In Chogoria Forest at $2460 \mathrm{~m}$, light and medium morphs were found together, but in different microhabitats: the light morph among vegetation, with the apex of the domed web attached to the underside of a green leaf (Fig. 8); the medium morph close to the ground, with the same type of web among mosses and in small cavities. However, in other localities, light and medium/dark morphs were collected by fogging (see below), suggesting that medium/dark morphs also occur higher in the vegetation (on mosses of trees?). Low molecular distances (Dimitrov, Astrin \& Huber 2012) and indistinguishable genitalia suggest that this might be a case of ecological speciation at an early stage.

\section{New records}

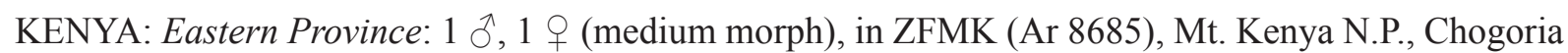

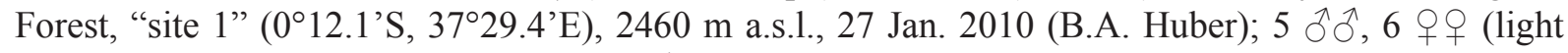
morph) in ZFMK (Ar 8686), same data; 1 ${ }^{\Uparrow}, 3$ 우, 1 juv. (light morph) in pure ethanol, in ZFMK (Ken

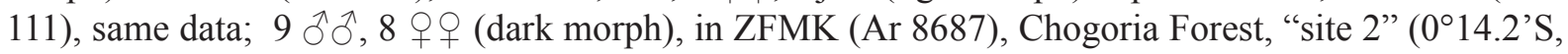
37³4.0’E), $1950 \mathrm{~m}$ a.s.1., 27 Jan. 2010 (B.A. Huber); 1 §, 3 q in pure ethanol, in ZFMK (Ken 120),

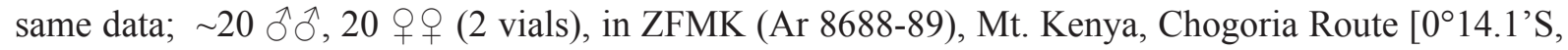
37³3.1'E], $2000 \mathrm{~m}$ a.s.l., 21 Oct. 2002 (T. Wagner), fogging of Podocarpus latifolius; $\sim 60{ }^{\lambda}{ }^{\lambda}, 60$ 우우 (3 vials), in ZFMK (Ar 8690-92), same data but $2500 \mathrm{~m}$ a.s.1. [0 ${ }^{\circ} 11.8^{\prime} \mathrm{S}, 37^{\circ} 29.1^{\prime} \mathrm{E}$ ], 19 Oct. 2002; 80 $\mathrm{O}^{\top} \mathrm{o}^{\lambda}, 80$ 우 (3 vials), in ZFMK (Ar 8693-95), same data but $3000 \mathrm{~m}$ a.s.1. [ $0^{\circ} 09.1^{\prime} \mathrm{S}, 37^{\circ} 26.1^{\prime} \mathrm{E}$ ], 16 Oct.

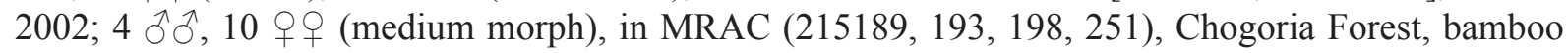
forest at $2660 \mathrm{~m}$ a.s.1. [0¹1.0'S, 37²7.9'E], 24 Apr. 2004 (R. Jocqué, C. Warui, van den Spiegel); 1 q, in MRAC (161912), Sirimon track at 2650 m a.s.1. [000.2'S, 37¹5.6’E], 23 Jul. 1975 (R. Bosmans). Central Province: 13 §ึㅅ, 23 우우 (dark morph), in ZFMK (Ar 8696-97), Mt. Kenya N.P., Naro Moru Forest, overhangs along road ( $\left.0^{\circ} 10.2^{\prime}-10.6^{\prime} \mathrm{S}, 37^{\circ} 12.0^{\prime}-13.3^{\prime} \mathrm{E}\right), 2800-3200 \mathrm{~m}$ a.s.1., 29 Jan. 2010 (B.A. Huber); $2 \widehat{\jmath}, 4$ 우 in pure ethanol, in ZFMK (Ken 124), same data; 1 ภ, 2 ㅇ+ (medium morph), in ZFMK (Ar 8698), same data; 2 ㅇ, 1 juv. (medium morph) in pure ethanol, in ZFMK (Ken 125), same data; 11 ฮิ $\widehat{\partial}, 10$ 우 (dark morph), in ZFMK (Ar 8699), Mt. Kenya N.P., above Naro Moru Forest, small cave $\left(0^{\circ} 10.0^{\prime} \mathrm{S}, 37^{\circ} 14.0^{\prime} \mathrm{E}\right), 3580 \mathrm{~m}$ a.s.l., 29 Jan. 2010 (B.A. Huber); 1 ¡̊, 3 우, 2 juvs. in pure ethanol, in ZFMK (Ken 127), same data; 1 ऽ, 5 9 ( (4 vials; dark and medium morphs), in ZFMK (Ar 8700-03), Mt. Kenya N.P. (West) $\left(0^{\circ} 10^{\prime} \mathrm{S}, 37^{\circ} 09^{\prime} \mathrm{E}\right), 2550 \mathrm{~m}$ a.s.1., fogging of Podocarpus latifolius, Feb.1999 (T. Wagner); 3 우 (2 vials, medium and dark morphs), in ZFMK (Ar 8704-05), same data but

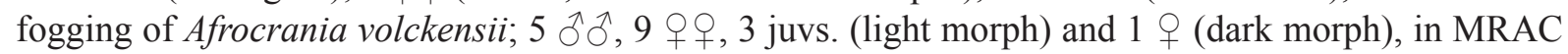
$(215075,125,132,133,393)$, Castle Forest, $1.5 \mathrm{~km} \mathrm{~S}$ of lodge [0²3.5'S, 37'18.6'E], $1985 \mathrm{~m}$ a.s.1., 21 Apr. 2004 (R. Jocqué, C. Warui, van den Spiegel); 1 q (light morph), in MRAC (215141), same data but clearing of forest near lodge [ $\left.0^{\circ} 22.9^{\prime} \mathrm{S}, 37^{\circ} 18.7^{\prime} \mathrm{E}\right], 2025 \mathrm{~m}$ a.s.l.; 5 ๙ $\partial^{\lambda}, 23$ 우우 (medium morph), in MRAC (215161), same data but bamboo forest at $2445 \mathrm{~m}$ a.s.1. [0 $\left.0^{\circ} 19.9^{\prime} \mathrm{S}, 37^{\circ} 19.0^{\prime} \mathrm{E}\right] ; 33 \mathrm{o}^{\wedge} \mathrm{o}^{\wedge}, 77^{\circ}$ 우 (10 vials; mostly medium morph, few dark morph), in ZFMK (Ar 8706-15), Aberdare National Park at

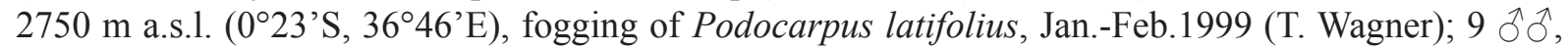
23 우 (5 vials; light, medium, and dark morphs), in ZFMK (Ar 8716-17, 19-21), Kikuyu Escarpment, Gatamaiyu ( $\left.0^{\circ} 58^{\prime} \mathrm{S}, 36^{\circ} 42^{\prime} \mathrm{E}\right), 2330 \mathrm{~m}$ a.s.l., mountain forest, fogging of Podocarpus latifolius, Feb.

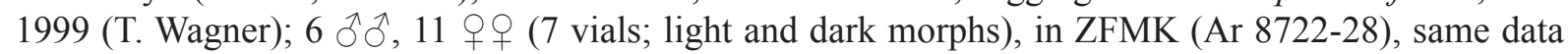
but fogging of Tabernaemontana stapfiana, 18-23 Jan. 1999; 2 소, 10 우 (4 vials, light, medium, and dark morphs), in ZFMK (Ar 8729-32), same data but fogging of Teclea nobilis, 18-23 Jan. 1999. Western Province: 1 ô, 3 qo, 1 juv. (dark morph), in ZFMK (Ar 8733), Kakamega Forest N.P., near Isiukhu River Falls $\left(0^{\circ} 21.1^{\prime}\right.$ N, 34 $4^{\circ} 52.1^{\prime}$ E), 1580 m a.s.1., 2-3 Feb. 2010 (B.A. Huber); 1 ㅇ, 3 juvs. in pure ethanol, in ZFMK (Ken 140), same data. Rift Valley: 8 $\sigma^{\lambda}, 11$ q $q$, juvs. (dark morph), in ZFMK (Ar 8734), Thompson Falls near Nyahururu, $\left(0^{\circ} 02.7^{\prime} \mathrm{N}, 36^{\circ} 22.1^{\prime} \mathrm{E}\right), 2350 \mathrm{~m}$ a.s.1., 30 Jan. 2010 (B.A.

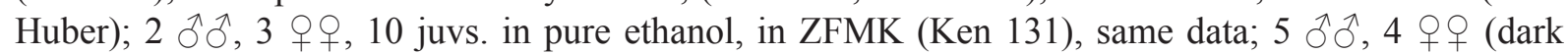
morph), in ZFMK (Ar 8735), Mau Escarpment between Kericho and Molo, forest fragment near road 
( $\left.0^{\circ} 14.3^{\prime} \mathrm{S}, 35^{\circ} 32.7^{\prime} \mathrm{E}\right), 2130 \mathrm{~m}$ a.s.1., 4 Feb. 2010 (B.A. Huber); 1 ㅇ, 5 juvs. in pure ethanol, in ZFMK (Ken 137), same data; 1 ㅇ, in CJFM (1543), Kitale, Kaibos [1 ${ }^{\circ} 12^{\prime} \mathrm{N}, 35^{\circ} 08^{\prime} \mathrm{E}$ ?].

84. Spermophora morogoro Huber, 2003. Tanzania (Huber 2003a).

85. Spermophora sangarawe Huber, 2003. Tanzania (Huber 2003a).

\section{New record}

TANZANIA: 1 , 2 juvs. in CAS, Tanga Region: E Usambara Mountains, Amani, Mbomole Hill (505.7’S, 38³7’'E), 1000 m a.s.1., 5-8 Nov. 1995 (Griswold, Scharff, Ubick).

86. Spermophora usambara Huber, 2003. Tanzania (Huber 2003a).

\section{New record}

TANZANIA: $37 \lesssim \precsim, 63$ 우 (79 vials, partly without date and altitude data) in ZMUC, Tanga Region, Lushoto Distr., Mazumbai Forest Reserve (449’S, 38²9'-31'E), 1370-1730 m a.s.1., Jul. 1995 (ZMUC expedition).

\section{Spermophorides Wunderlich, 1992}

Spermophorides is largely restricted to the Canary Islands and the southwestern Mediterranean (Wunderlich 1992). A single species has been collected in mainland Africa (Huber 2007) (Fig. 21).

87. Spermophorides africana Huber, 2007. Tanzania (Huber 2007).

\section{Identification key to East African pholcid genera}

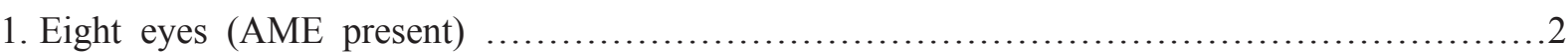

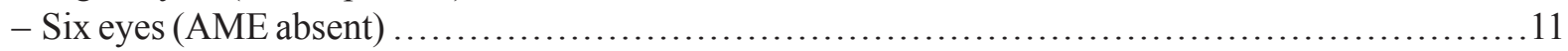

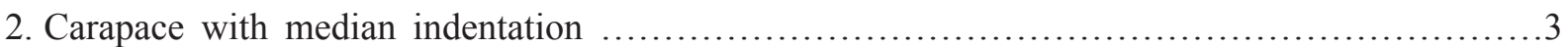

- Carapace domed, without median indentation ..............................................

3. Abdomen cylindrical (Fig. 3), not elevated posteriorly ........................Smeringopus

- Abdomen globular or slightly elongated and elevated above spinnerets (Figs 28, 30) ..........4

4. Legs with many small black marks on femora and tibiae (Figs 28, 30); male femora 1 with row

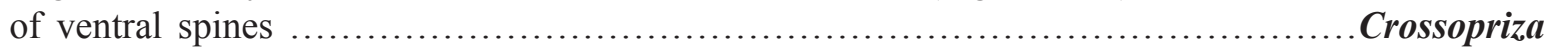

- Legs without small black marks (only few dark rings); male femora 1 without spines ...5

5. Procursus with prominent distal spine, female carapace with posterior median cone acting against frontal plate on abdomen ..........................Physocyclus globosus (Taczanowski, 1874)

- Procursus short, without distal spine; female carapace without posterior cone

6. Abdomen globular; short legs (leg $1<3 \mathrm{x}$ body length) Ninetis

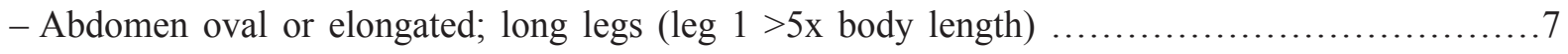

7. Abdomen drawn into cone dorso-posteriorly (fig. 29 in Huber 2011) .............Pehrforsskalia

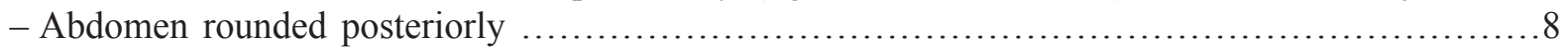




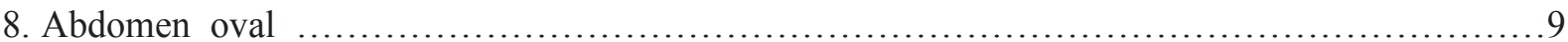

- Abdomen cylindrical or worm-shaped (Figs 2, 4) ..................................... 10

9. Procursus with long hinged dorsal process, epigynum weakly sclerotized, internal U-shaped structure visible through cuticle frontally (figs 83-89 in Huber 2011) ...Micropholcus fauroti (Simon, 1887)

- Procursus widely curved, without long dorsal process (figs 204-205 in Huber 2003b); female unknown Quamtana kitahurira Huber, 2003

10.Male chelicerae with pair of lateral unsclerotized projections in distal position; tip of male palpal trochanter apophysis serrated (e.g., figs 301-303 in Huber 2011); epigynum weakly sclerotized

Leptopholcus

- Male chelicerae with pair of lateral unsclerotized projections in proximal position or absent; tip of male palpal trochanter apophysis not serrated (e.g., figs 1163-1165 in Huber 2011); epigynum strongly sclerotized

Pholcus

11. Eyes close together on turret, in male with frontal hairy pocket; male chelicerae with pair of small frontal apophyses, without proximal lateral projections (figs 2-4 in Huber 1996)

Modisimus culicinus (Simon, 1893)

- Eyes not on turret; male chelicerae with proximal lateral projections .12

12.Sternum with unique pattern of dark lines radiating from behind labium; male palpal tibia globular, much larger than femur (figs 8, 33 in Huber 2007) ......................Anansus

- Sternum pattern different; male palpal tibia not globular, usually not much larger than femur

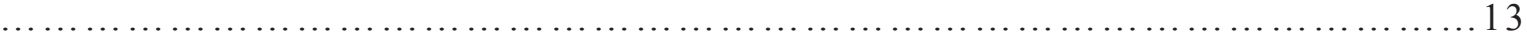

13.Procursus attachment to tarsus distal rather than proximal; anterior and posterior epigynal sclerite with one pair of pockets each (figs 62-66 in Huber 2007) ..........Spermophorides

- Procursus attachment to tarsus rather proximal; posterior epigynal sclerite without pair of pockets ...14

14.Prolateral attachment of bulb to tarsus; proximal bulbal sclerite strongly developed (Figs 107, 112); epigynum with pair of external pockets, never with scape .................................... 15

- Dorsal attachment of bulb to tarsus (e.g., Figs 75, 87, 97); proximal bulbal sclerite absent or poorly developed and hidden; epigynum without pair of pockets, often with scape ...........16

15.Male frontal cheliceral apophyses small (Fig. 113), close together; corresponding female pockets (poorly visible in dissecting microscope) also close together ......Quamtana (except Q. kitahurira)

- Male frontal cheliceral apophyses large (Fig. 109), wide apart; corresponding female pockets (poorly visible in dissecting microscope) also wide apart Spermophora kyambura sp. nov.

16.Procursus without ventral flap (e.g. Figs 76, 82) Buitinga

- Procursus with ventral flap (e.g. Figs 88, 93, 98, 103) ...Spermophora (except S. kyambura sp. nov.) 


\section{Taxonomy}

Crossopriza johncloudsleyi Deeleman-Reinhold \& van Harten, 2001

Figs 28-31, 62-63, 70-74

Crossopriza johncloudsleyi Deeleman-Reinhold \& van Harten, 2001: 197-199; figs 11-16, 주우우 (Yemen).

\section{Diagnosis}

Easily distinguished from known congeners by male clypeus modification (shapes of pair of apophyses; Fig. 29), male palp (shapes of procursus and bulbal process; Figs 70, 71), and distinctive epigynum (large pits and lateral processes; Figs 30, 62, 73).

\section{Type material}

\section{Holotype}

$\lambda$, examined.

\section{Paratypes}

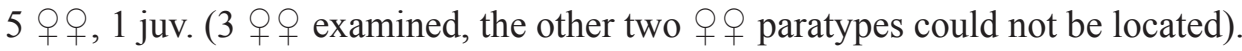

\section{Type locality}

YEMEN, Ja' $\operatorname{ar}\left(13^{\circ} 13^{\prime} \mathrm{N}, 45^{\circ} 18^{\prime} \mathrm{E}\right), 50$ m a.s.1., 15-16 May 2000 (A. van Harten), in RMNH (15173).

\section{Other material examined}

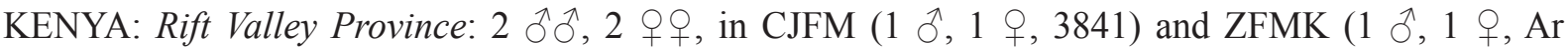
8736), Lake Hannington [ $=$ Lake Bogoria, $\sim 0^{\circ} 15^{\prime} \mathrm{N}, 36^{\circ} 05^{\prime} \mathrm{E}$ ], $1000 \mathrm{~m}$ a.s.l., lakeside scrub, 2 Aug. 1974 (Murphy); 2 q $ᄋ$, in CJFM (2275), Lake Baringo [ $\sim 0^{\circ} 38^{\prime}$ N, 3601'E, 980 m a.s.1.], 28 Aug. 1972 (Murphy); 1 ㅇ, in CJFM (3805), Baringo, near hot springs, 1100 m a.s.1., 31 Jul. 1974 (Murphy); 1 ㅇ, 2 juvs., in $\mathrm{MCZ}$ (34026), Lokori [ $1^{\circ} 58^{\prime} \mathrm{N}, 3^{\circ} 06^{\prime} \mathrm{E}, 600 \mathrm{~m}$ a.s.l.], 16 Aug. 1965 (B. Patterson Expedition); 1 q, in MCZ (34012), 15 miles ENE Lokori [ $2^{\circ} 02^{\prime} \mathrm{N}, 36^{\circ} 18^{\prime} \mathrm{E}, 600 \mathrm{~m}$ a.s.1.], 28-29 Jun. 1966 (collector not given); $1 \partial^{\top}$, in MCZ (34022), Lothagam ( ${ }^{\circ} 56^{\prime} \mathrm{N}, 36^{\circ} 04^{\prime} \mathrm{E}$ ) [ $400 \mathrm{~m}$ a.s.1.], $2-5$ Aug. 1967 (B. Patterson); 1 +, in MCZ (34018), Kangatotha ("40 km E of Lodwar, W of Lake Rudolf")

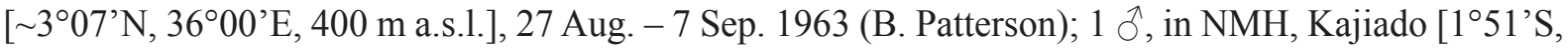
$36^{\circ} 47^{\prime} \mathrm{E}, 1700 \mathrm{~m}$ a.s.l.], road culverts, May 1973 (collector not given).

\section{Description}

Male (Lake Bogoria)

MeAsurements. Total body length 2.8, carapace width 1.2. Leg 1: $21.0(6.0+0.5+5.8+7.2+1.5)$, tibia 2: 3.7, tibia 3: 2.7, tibia 4: 3.3; tibia $1 \mathrm{~L} / \mathrm{d}: 50$. Distance PME-PME $70 \mu \mathrm{m}$, diameter PME $85 \mu \mathrm{m}$, distance PME-ALE $35 \mu \mathrm{m}$, distance AME-AME $25 \mu \mathrm{m}$, diameter AME $85 \mu \mathrm{m}$.

CoLOR. Carapace ochre-yellow, medially slightly darker including ocular area and clypeus, sternum light brown with slightly darker radiating marks, legs ochre-yellow with many small black marks, mostly on femora (Fig. 28) and tibiae, not on coxae, few on metatarsi, abdomen ochre-grey with indistinct small dark and white internal marks dorsally and laterally, ventrally with darker pattern, wider anterior of gonopore.

Body. Habitus as in Figs 28 and 29; ocular area elevated, compact, no 'accessory eyes' (cf. Huber 2009); carapace with thoracic pit; clypeus with pair of distally slightly hooked apophyses on rim, $\sim 140 \mu \mathrm{m}$ 
long. Chelicerae as in Fig. 72, with large frontal apophyses provided with one thick modified hair each and pair of smaller apophyses laterally, some hair bases accompanied by small cuticular elevations, fine stridulatory ridges. Sternum wider than long $(0.78 / 0.50)$, unmodified.

PALPS. As in Figs 70 and 71, coxa with prominent joint (arrow) and retrolateral hump, trochanter simple, femur with distinct ventral apophysis, tibia very large, procursus curved towards femur, with strong
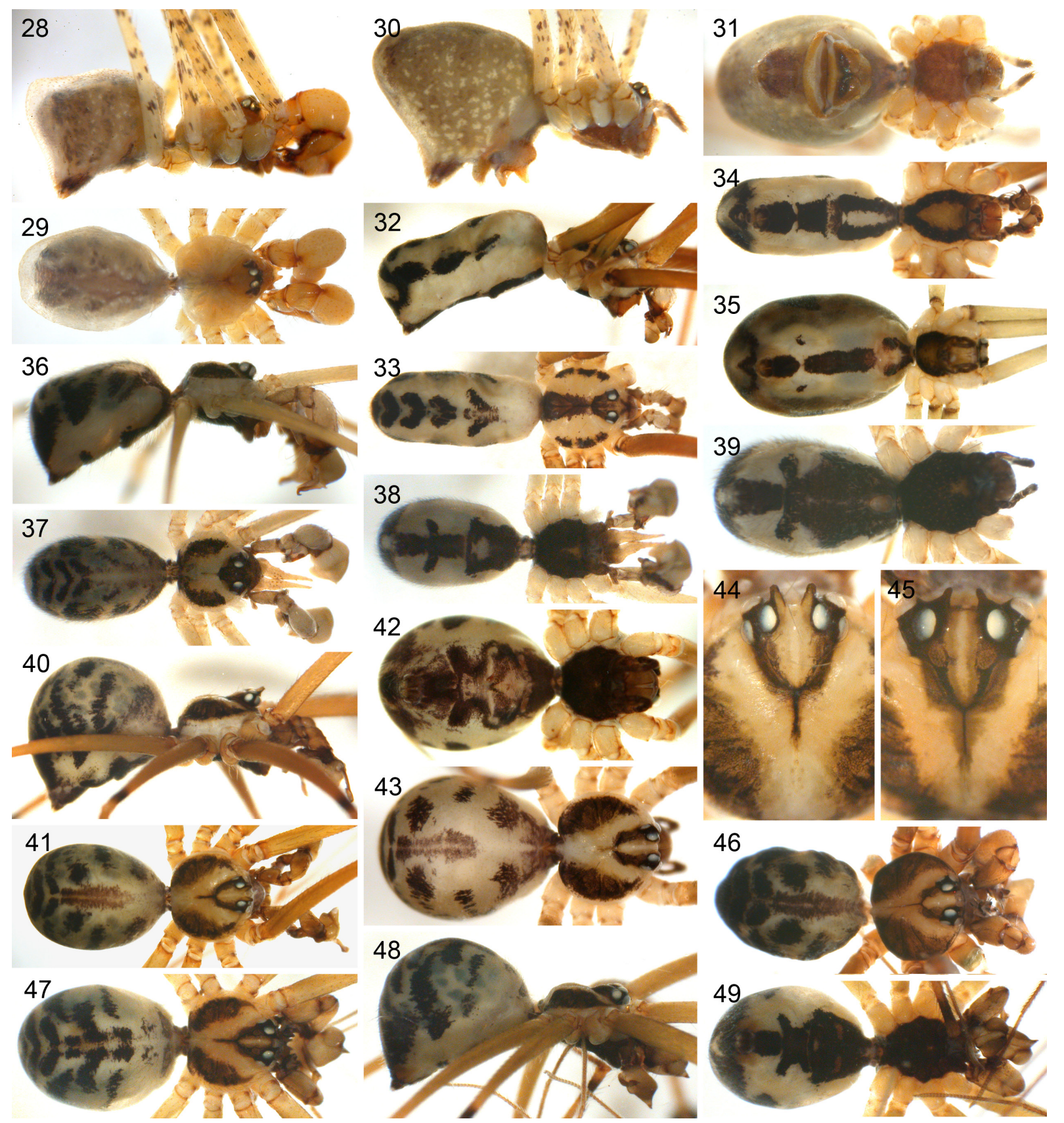

Figs 28-49. - 28-31. Crossopriza johncloudsleyi Deeleman-Reinhold \& van Harten, 2001, ô $(28,29)$ and $q$ (30, 31). - 32-35. Buitinga wataita sp. nov., $\hat{\partial}(32-34)$ and $q$ (35). - 36-39. Buitinga batwa sp. nov., ô (36-38) and $q$ (39). - 40-44. Spermophora mau sp. nov., ô (40, 41, 44) and $q$ (42, 43). - 46. Spermophora maathaiae sp. nov., $\hat{\jmath}$. - 45, 47-49. Spermophora bukusu sp. nov., $\widehat{\partial}$. 

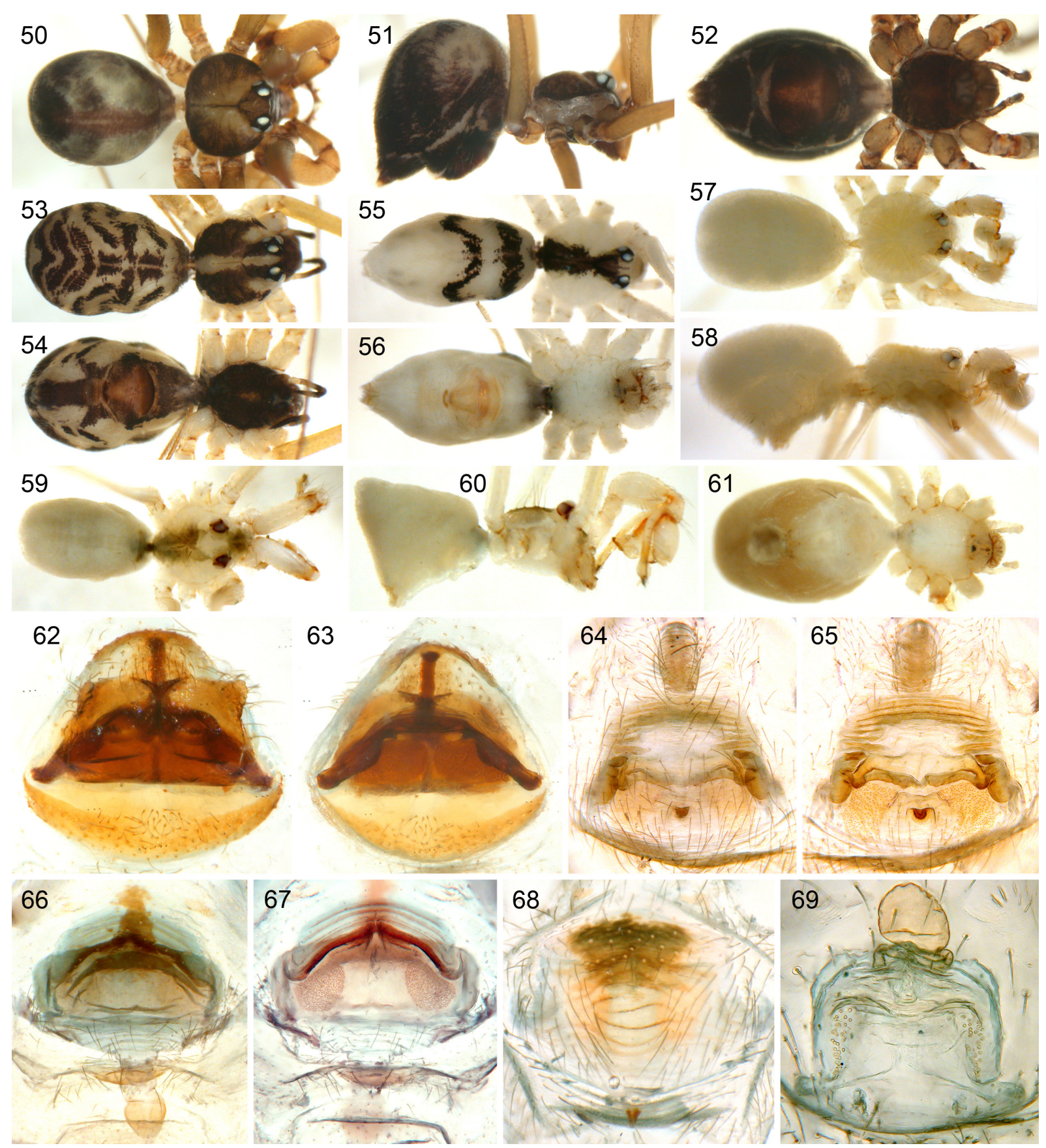

Figs 50-69. - 50-52. Spermophora kirinyaga sp. nov., ô (50) and $q$ (51, 52). - 53-56. Spermophora minotaura Berland, 1920, 9 , , dark morph $(53,54)$ and light morph $(55,56)$. - 57-58. Spermophora kyambura sp. nov., $\widehat{\jmath}$. - 59-61. Quamtana nyahururu sp. nov., $\widehat{O}(59,60)$ and $q$ (61). 62-63. Crossopriza johncloudsleyi Deeleman-Reinhold \& van Harten, 2001, cleared 9 genitalia, ventral and dorsal views. - 64-65. Buitinga batwa sp. nov., cleared + genitalia, ventral and dorsal views. 66-67. Spermophora maathaiae sp. nov., cleared $q$ genitalia, ventral and dorsal views. 68. Spermophora bukusu sp. nov., cleared $q$ genitalia, ventral view. - 69. Spermophora kyambura sp. nov., cleared $P$ genitalia, dorsal view. 
distal apophysis, bulb with only one process (bulbal apophysis) with distinctive prolatero-ventral ridges, sperm duct apparently opening at basis of bulbal apophysis.

LEGS. Without curved hairs, few vertical hairs, with spines ventrally on femur 1 (single row on distal half, $\sim 17$ spines); retrolateral trichobothrium on tibia 1 at $4 \%$; prolateral trichobothrium absent on tibia 1 , present on other tibiae; pseudosegments not visible in dissecting microscope.

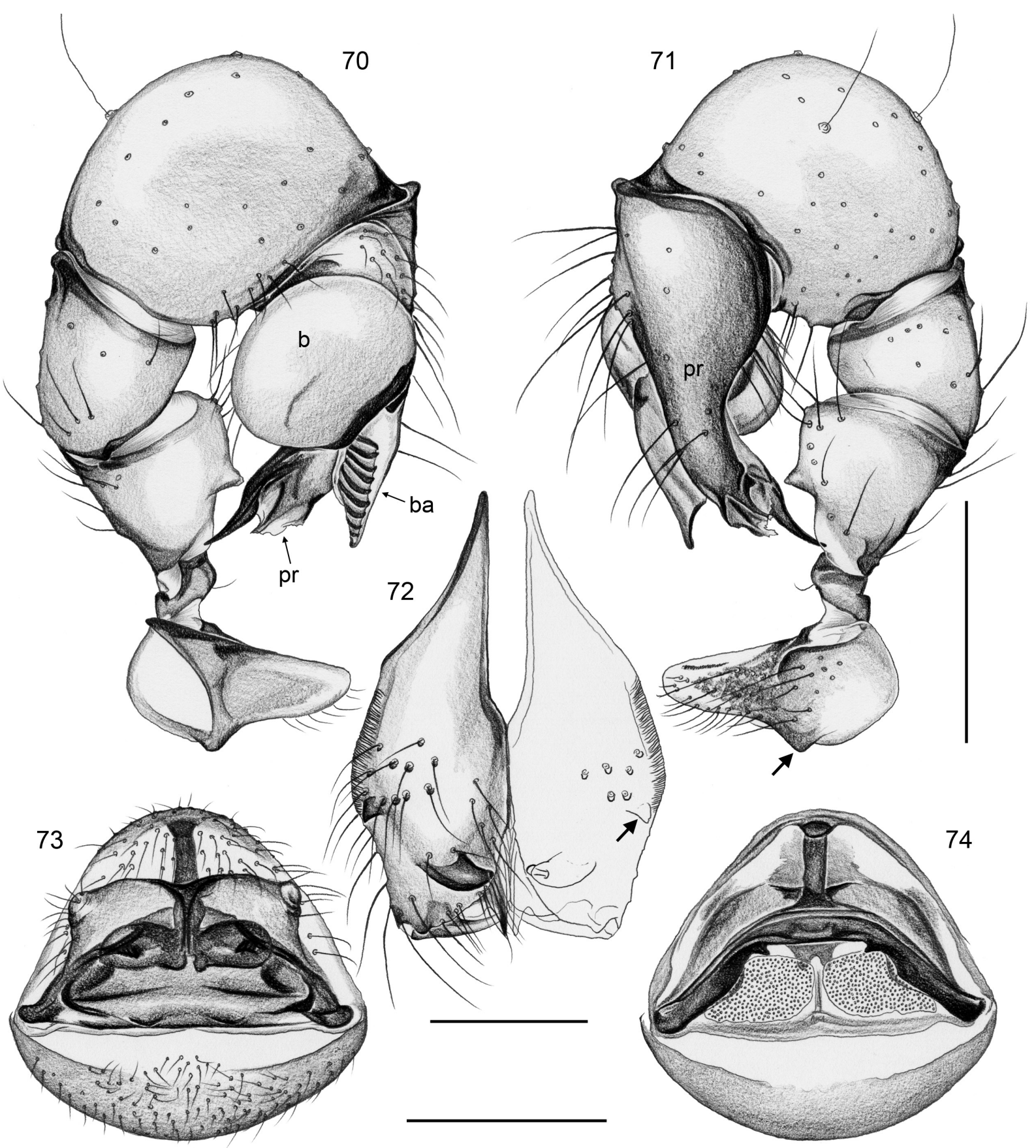

Figs 70-74. Crossopriza johncloudsleyi Deeleman-Reinhold \& van Harten, 2001. 70-71. Left $\partial$ palp, prolateral and retrolateral views (arrow points to distinctive joint on coxa). 72 . $\delta$ chelicerae, frontal view. 73-74. $q$ genitalia, ventral and cleared dorsal views. b: genital bulb; ba: bulbal apophysis; pr: procursus. Scale lines: $0.2 \mathrm{~mm}$ (72), $0.5 \mathrm{~mm}(70-71,73-74)$. 
VARIATION. Tibia 1 in two other males from Kenya: 5.6, 5.7. The holotype is slightly smaller (tibia 1: 4.5), lacks the small proximal apophyses on the chelicerae (arrow in Fig. 72), and has a slightly differently shaped palpal femur (ventral projection; see fig. 15 in Deeleman-Reinhold \& van Harten 2001).

\section{Female}

In general similar to male but femur 1 without spines, clypeus unmodified, chelicerae without stridulatory ridges; tibia 1 in 6 females from Kenya: 4.6-5.2 (mean 4.8); in 3 females from Yemen: 3.4-3.5. Without stridulatory apparatus between prosoma and abdomen. Epigynum with large and complex frontal plate with pair of long lateral apophyses, pair of deep pits, and posterior elevated transversal ridge; simple posterior plate; internal genitalia as in Figs 63 and 74. Paratypes with slightly smaller epigyna with slightly shorter projections, otherwise identical (also in dorsal view). ALS with only two spigots each.

\section{Distribution}

Known from Yemen and from several localities in Kenya, Rift Valley Province (Fig. 19).

Buitinga wataita sp. nov. urn:lsid:zoobank.org:act:E19D0275-54F4-4F89-BF12-D2AF12B7276A

Figs $32-35,75-80$

Buitinga Kenya 5: Dimitrov, Astrin \& Huber 2012 (DNA sequence data).

\section{Diagnosis}

Distinguished from known congeners by combination of male cheliceral armature (Fig. 77), male palp (shapes of procursus and bulbal process; Figs 75, 76), color pattern on prosoma and abdomen (Figs 3235), and epigynum with straight scape in anterior position and distinctive posterior structure (Fig. 78).

\section{Etymology}

The species is named after the Taita people (also Wataita or Wadawida), a Kenyan ethnic group located in the Taita-Taveta District; noun in apposition.

\section{Type material}

\section{Holotype}

o, in ZFMK (Ar 8737).

\section{Paratypes}

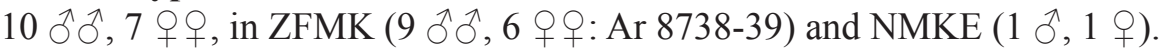

\section{Type locality}

KENYA, Coast Province, Taita Hills, Ngangao Forest (3²2.2'S, 38²0.4'E), 1810 m a.s.1., 19 Jan. 2010 (B.A. Huber).

\section{Other material examined}

KENYA: Coast Province: $4 \hat{\sigma} \hat{\partial}, 3$ 우 in pure ethanol, in ZFMK (Ken 89), Taita Hills, Ngangao Forest, same data as types above; 1 \%, 1 juv., in MRAC (209580), Ngangao Forest, 1720 m a.s.1., sweeping

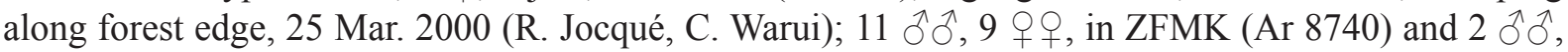
2 우, in NMKE, Taita Hills, Macha Forest ( $3^{\circ} 25.3^{\prime}$ 'S, 38 $8^{\circ} 21.5^{\prime}$ E), 1610 m a.s.l., 20 Jan. 2010 (B.A.

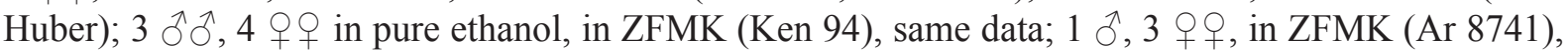

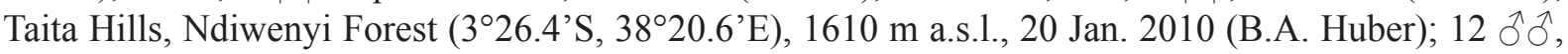

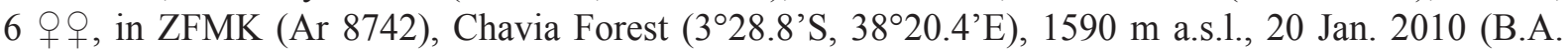




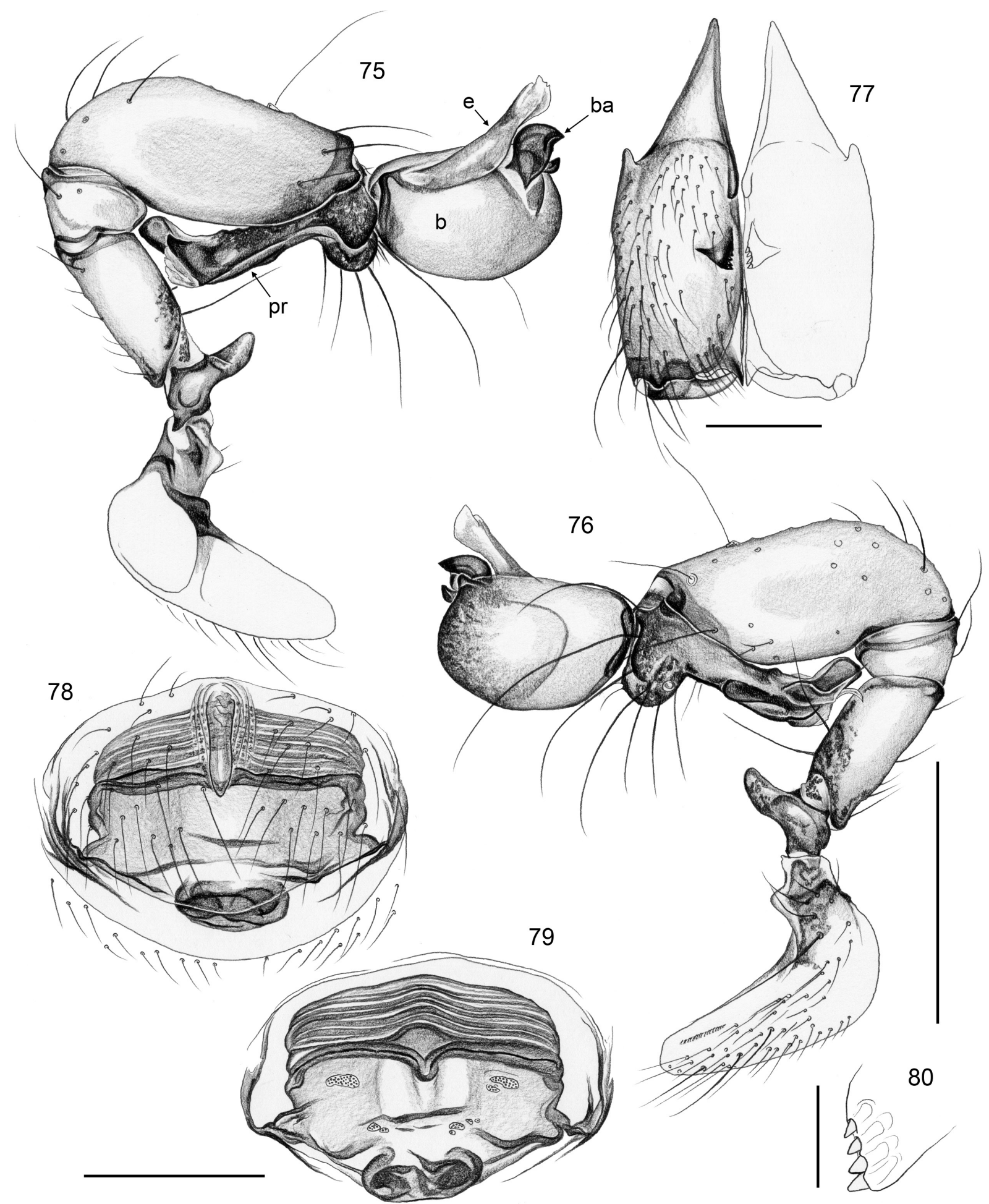

Figs 75-80. Buitinga wataita sp. nov. 75-76. Left $\widehat{\partial}$ palp, prolateral and retrolateral views. $77 . \widehat{\partial}$ chelicerae, frontal view. 78-79. . genitalia, ventral and cleared dorsal views. 80. $\hat{\sigma}$ cheliceral apophysis with modified hairs. b: genital bulb; ba: bulbal apophysis; e: embolus; pr: procursus. Scale lines: $0.05 \mathrm{~mm}(80), 0.2 \mathrm{~mm}(77), 0.3 \mathrm{~mm}(78,79), 0.5 \mathrm{~mm}(75,76)$. 
Huber); 2 + $q$ in pure ethanol, in ZFMK (Ken 95), same data; 1 ภ, 1 +, 1 juv., in CAS, S slopes Taita Hills, 1030 m a.s.1., 30 Oct. 1957 (E.S. Ross, R.E. Leech).

\section{Description}

Male (holotype)

MEAsurements. Total body length 3.4, carapace width 1.3. Leg 1: $27.0(6.8+0.5+6.5+10.4+2.8)$, tibia 2: 4.1, tibia 3: 3.0, tibia 4: 4.0; tibia 1 L/d: 41. Distance PME-PME $185 \mu \mathrm{m}$, diameter PME $90 \mu \mathrm{m}$, distance PME-ALE $55 \mu \mathrm{m}$, no AME.

CoLor. Prosoma pale whitish with black pattern on carapace including ocular area and clypeus, sternum with wide black lateral V-shaped margins, legs ochre-yellow, darker rings on femora (subdistally) and tibiae (proximally and subdistally), tips of femora and tibiae lighter, abdomen pale grey with distinctive black pattern.

BoDy. Habitus as in Figs 32-34; ocular area slightly elevated; no thoracic furrow, with small median cone on carapace posteriorly; clypeus unmodified. Chelicerae as in Fig. 77, with proximal lateral apophyses, pair of small apophyses proximally near median line, and frontal apophyses in relatively proximal position provided with four modified hairs each (Fig. 80). Sternum as wide as long (0.65), unmodified.

PALPS. As in Figs 75 and 76, coxa and trochanter each with retrolatero-ventral apophysis, femur barely modified, trichobothria on tibia very distal, procursus strongly bent back towards femur, distally complex, bulb with simple weakly sclerotized embolus and distinctive pincer-shaped apophysis accompanied by small sclerotized cone.

LEGS. Without spines and curved hairs, few vertical hairs; retrolateral trichobothrium on tibia 1 at $7 \%$; prolateral trichobothrium absent on tibia 1, present on other tibiae; tarsus 1 with $\sim 20$ pseudosegments.

VARIATION. The color patterns are very constant but two elements may be less distinct or even missing: the anterior dorsal abdominal mark and the anterior lateral pair of marks on the carapace. Tibia 1 in 35 other males: 5.8-6.9 (mean 6.4).

\section{Female}

In general similar to male but ventral abdominal pattern slightly different (anterior paired element shorter, median element longer; Fig. 35), triads closer together (distance PME-PME $140 \mu \mathrm{m}$ ), and carapace without median cone. Tibia 1 in 25 females: 4.5-5.7 (mean 5.2). Epigynum a simple plate with straight scape in anterior position, with distinctive structure posteriorly (Fig. 78); internal genitalia as in Fig. 79, with small pore plates scattered over wide area.

\section{Distribution}

Known from Taita Hills only (Fig. 18).

Buitinga batwa sp. nov. urn:1sid:zoobank.org:act:C456910B-9E7B-4872-830B-87F240C313E3

Figs 13, 36-39, 81-86

Buitinga Uga 61: Dimitrov, Astrin \& Huber 2012 (DNA sequence data).

\section{Diagnosis}

Easily distinguished from known congeners by extremely long male cheliceral apophyses (Figs 83, 84); from similar B. buhoma Huber, 2003 also by wider epigynal scape and median pocket in internal female 
genitalia (Figs 65, 85), and by details of male palp (shape of bulbal apophysis, two small projections on bulb apart from apophysis and embolus, shapes of distal structures of procursus; Figs 81, 82).

\title{
Etymology
}

The species is named after the Batwa pygmies of south-western Uganda; noun in apposition.

\section{Type material}

\section{Holotype}

o, in ZFMK (Ar 8743).

\author{
Paratypes \\ 3 ふึ, 4 웅, in ZFMK (Ar 8744).
}

\section{Type locality}

UGANDA, Kisoro District, Mgahinga Gorilla N.P., gorge (1²2.9’'S, 29³5.8-36.0’'E), 2900-3000 m a.s.1., 25 Nov. 2010 (B.A. Huber).

\section{Other material examined}

UGANDA: Western Region: 1 ภ, 2 우, 1 juv. in pure ethanol, in ZFMK (Uga 147), Kisoro District, Mgahinga Gorilla N.P., gorge, same data as types above; $2 \hat{\jmath} \partial^{2}, 1$ ㅇ, in ZFMK (Ar 8745), Mgahinga Gorilla N.P., bamboo forest ( $1^{\circ} 22.0-22.3^{\prime}$ 'S, $\left.2^{\circ} 36.3-36.9^{\prime} \mathrm{E}\right), 2500-2600$ m a.s.1., 25 Nov. 2010 (B.A.

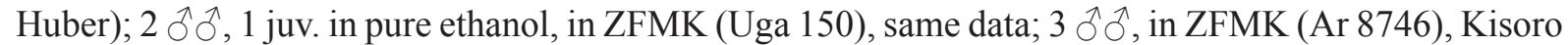
District, between Nyakabande and Muko, roadside forest ( $1^{\circ} 15.2^{\prime}$ S, $\left.29^{\circ} 47.6^{\prime} \mathrm{E}\right), 2260 \mathrm{~m}$ a.s.l., 26 Nov. 2010 (B.A. Huber).

\section{Description}

Male (holotype)

MEASUREMENTS. Total body length 2.7, carapace width 1.0. Leg 1: $19.5(4.6+0.4+4.8+7.3+2.4)$, tibia 2: 2.8, tibia 3: 2.2, tibia 4: 2.9; tibia $1 \mathrm{~L} / \mathrm{d}$ : 54. Distance PME-PME $185 \mu \mathrm{m}$, diameter PME $115 \mu \mathrm{m}$, distance PME-ALE $45 \mu \mathrm{m}$, no AME.

CoLor. Carapace pale ochre-yellow with black lateral marks, ocular area and clypeus dark brown to black, sternum black with slightly lighter mark behind labium; legs ochre-yellow, darker rings on femora (subdistally) and tibiae (proximally and subdistally); abdomen pale grey with distinctive black pattern.

Body. Habitus as in Figs 36-38; ocular area slightly elevated; only frontally shallow thoracic furrow; clypeus unmodified. Chelicerae as in Figs 83 and 84, with proximal lateral apophyses, pair of extremely long frontal apophyses, each provided with several strong claw-shaped hairs proximo-dorsally and about four modified hairs distally; without further pair of frontal apophyses near laminae. Sternum wider than long (0.70/0.57), unmodified.

PALPS. In general very similar B. buhoma Huber, 2003 (cf. figs 113 and 114 in Huber 2003a) but coxa with prominent ventral apophysis distally and tibia slightly longer; bulb with four projections: weakly sclerotized embolus, hooked apophysis with subdistal sclerotized ridge, small projection at basis of apophysis (arrow in Fig. 82), and pointed cone-shaped process (arrow in Fig. 81); procursus with large cushion-like structure retrolaterally, prolateral hinged process, complex distally.

LEGS. Without spines and curved hairs, few vertical hairs; retrolateral trichobothrium on tibia 1 at $10 \%$; prolateral trichobothrium absent on tibia 1, present on other tibiae; tarsus 1 with $\sim 30$ pseudosegments. 

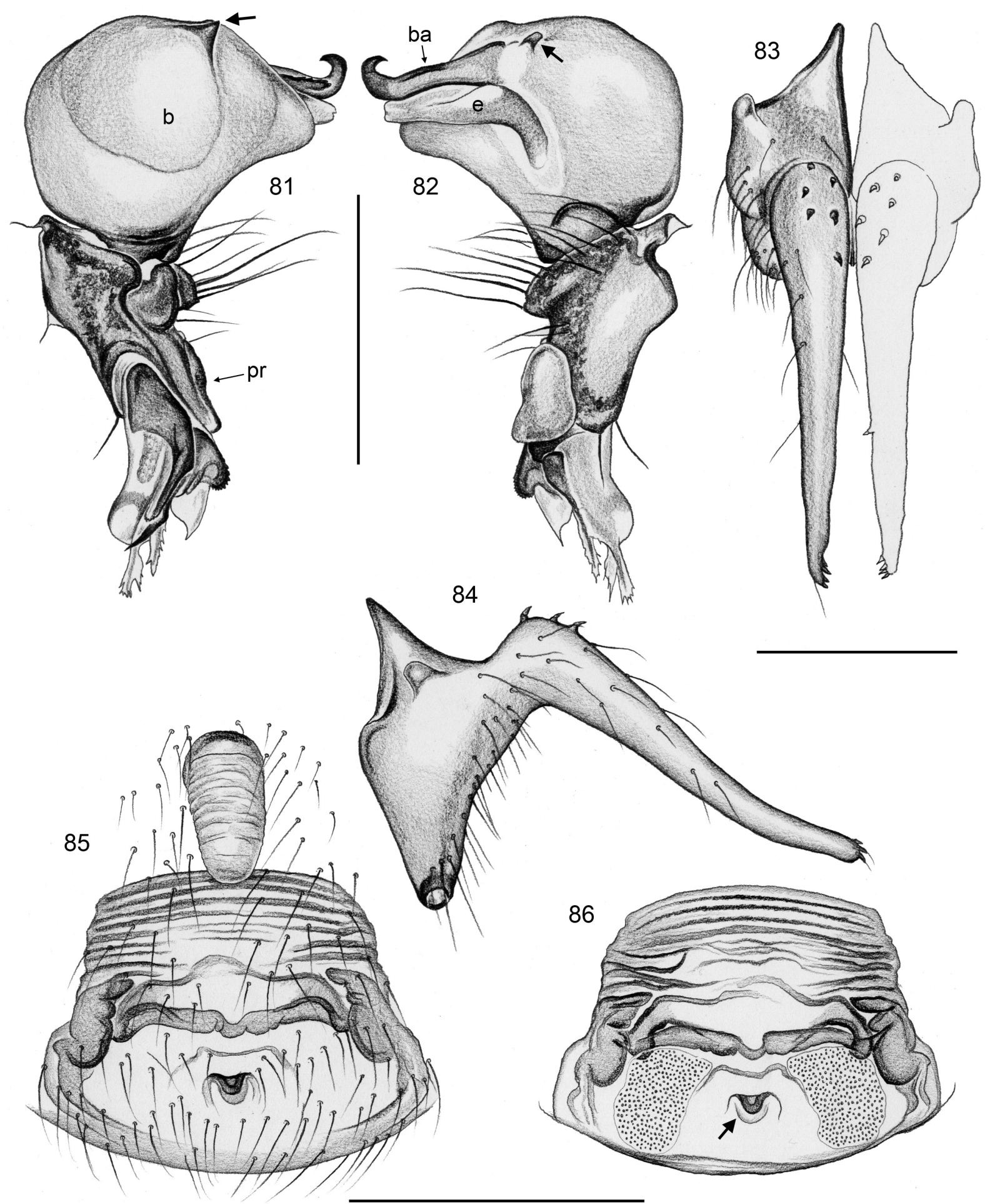

Figs 81-86. Buitinga batwa sp. nov. 81-82. Left $\widehat{\partial}$ procursus and bulb, prolateral and retrolateral views. 83-84. o chelicerae, fronto-dorsal and lateral views. 85-86. $q$ genitalia, ventral and cleared dorsal views (arrow points at distinctive internal pocket). b: genital bulb; ba: bulbal apophysis; e: embolus; pr: procursus. Scale lines: $0.3 \mathrm{~mm}(83-84), 0.5 \mathrm{~mm}(81-82,85-86)$. 
VARIATION. Tibia 1 in 9 other males: 4.4-5.2 (mean 4.7).

\section{Female}

In general similar to male but triads closer together (distance PME-PME $150 \mu \mathrm{m}$ ). Tibia 1 in 5 females: 3.5-3.9 (mean 3.75). Epigynum a simple plate with wide straight scape in anterior position (Figs 64, 85), with distinctive internal sclerotized pocket (arrow in Fig. 86) and large pore plates (Figs 65, 86).

\section{Distribution}

Known from southwestern Uganda only (Fig. 18).

Spermophora mau sp. nov. urn:1sid:zoobank.org:act:4717BA27-3070-47BB-A588-EB037A4F6294

Figs 9, 40-44, 87-91

Spermophora Ken 39: Dimitrov, Astrin \& Huber 2012 (DNA sequence data).

\section{Diagnosis}

Distinguished from very similar $S$. maathaiae sp. nov. by shape of female epigynal scape (longer; tip pointed; Fig. 90) and by details of procursus tip (slightly different shapes of sclerites; Figs 87, 88). From other species by male cheliceral armature (shapes of frontal apophyses; Fig. 89) and by pointed tip of female epigynal scape.

\section{Etymology}

The species name is derived from the type locality; noun in apposition.

\section{Type material}

\section{Holotype}

${ }^{1}$, in ZFMK (Ar 8747).

\section{Paratypes}

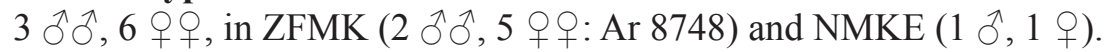

\section{Type locality}

KENYA, Rift Valley, Mau Escarpment near Elburgon (0²5.3'S, 3547.3'E), 2930 m a.s.1., 5 Feb. 2010 (B.A. Huber).

\section{Other material examined}

KENYA: Rift Valley: 2 qq, 2 juvs. in pure ethanol, in ZFMK (Ken 145), Mau Escarpment near Elburgon, same data as types above.

\section{Description}

Male (holotype)

MEASUREMENTS. Total body length 3.6, carapace width 1.3. Leg 1: $20.4(5.2+0.5+5.1+6.9+2.7)$, tibia 2: 3.3, tibia 3: 2.6, tibia 4: 3.4; tibia $1 \mathrm{~L} / \mathrm{d}:$ 41. Distance PME-PME $175 \mu \mathrm{m}$, diameter PME $125 \mu \mathrm{m}$, distance PME-ALE $55 \mu \mathrm{m}$, no AME.

Color. Prosoma ochre-yellow with large lateral black marks and Y-mark behind ocular area, ocular area laterally darkened, clypeus with pair of darker smudges below eye triads, sternum monochromous 


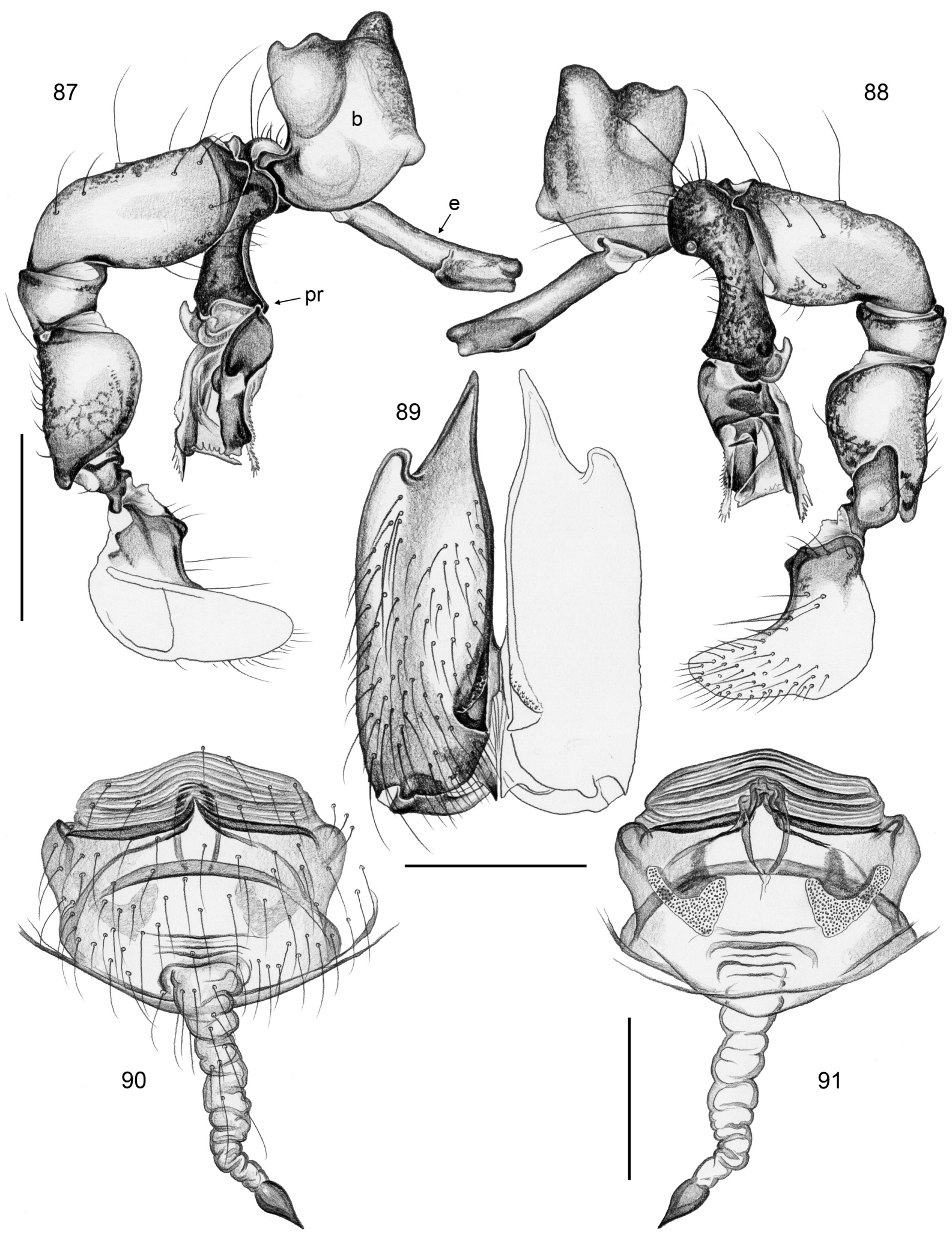

Figs 87-91. Spermophora mau sp. nov. 87-88. Left đิ palp, prolateral and retrolateral views. 89. §ิ chelicerae, frontal view. 90-91. + genitalia, ventral and cleared dorsal views. b: genital bulb; e: embolus; pr: procursus. Scale lines: $0.3 \mathrm{~mm}(89-91), 0.5 \mathrm{~mm}(87-88)$. 
black, legs ochre-yellow, with darker rings on femora (subdistally) and tibiae (proximally, subdistally), abdomen grey with distinctive black pattern dorsally and laterally, ventrally mostly black.

BoDy. Habitus as in Figs 40 and 41; ocular area elevated, with pair of horns between triads (Fig. 44); carapace only anteriorly with shallow thoracic furrow; clypeus unmodified. Chelicerae as in Fig. 89, each frontal apophysis forming a cup-shaped depression, without modified hairs. Sternum wider than long (0.94/0.72), unmodified.

PALPS. As in Figs 87 and 88, coxa with retrolatero-ventral apophysis, trochanter with retrolateral apophysis, femur barely modified (except dorsal apophysis proximally), procursus with ventral flap and several complex distal elements that appear hinged to proximal part, distinctive spine-like process visible in retrolateral view, bulb with three cone-shaped projections and long embolus.

LEGS. Without spines and curved hairs, few vertical hairs; retrolateral trichobothrium on tibia 1 at $10 \%$; prolateral trichobothrium absent on tibia 1, present on other tibiae; tarsus 1 with $>30$ pseudosegments, distinct distally.

VARIATION. Tibia 1 in 3 other males: 4.8, 4.9, 5.3.

\section{Female}

In general similar to male but triads closer together (distance PME-PME $135 \mu \mathrm{m}$ ), without horns. Tibia 1 in 6 females: 4.2-4.4. Epigynum a simple plate with long posterior scape ending in scorpion-tail-like tip (Fig. 90); internal genitalia as in Fig. 91.

\section{Distribution}

Known from type locality only (Fig. 27).

Spermophora maathaiae sp. nov. urn:1sid:zoobank.org:act:133558CC-190F-45DD-8178-A130F484A205

Figs 46, 66-67, 92-96

"Spermophora" sp. 1 indet.: Huber, 2003a: 601, map 4.

Spermophora cf. berlandi Dimitrov, Astrin \& Huber 2012 (DNA sequence data).

\section{Diagnosis}

Distinguished from very similar $S$. mau sp. nov. by shape of female epigynal scape (shorter; tip wide and rounded rather than pointed; Fig. 95) and by details of procursus tip (slightly different shapes of sclerites; Figs 92, 93). From other species by male cheliceral armature (shapes of frontal apophyses; Fig. 94) and by widened and sclerotized tip of female epigynal scape.

\section{Etymology}

The species is named in honor of Prof. Wangari Maathai, founder of the Green Belt Movement and first African woman to win the Nobel peace prize.

\section{Type material}

\section{Holotype}

${ }^{1}$, in ZFMK (Ar 8749).

\section{Paratypes}

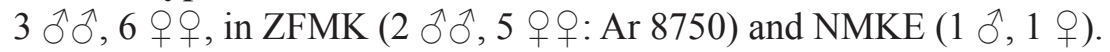



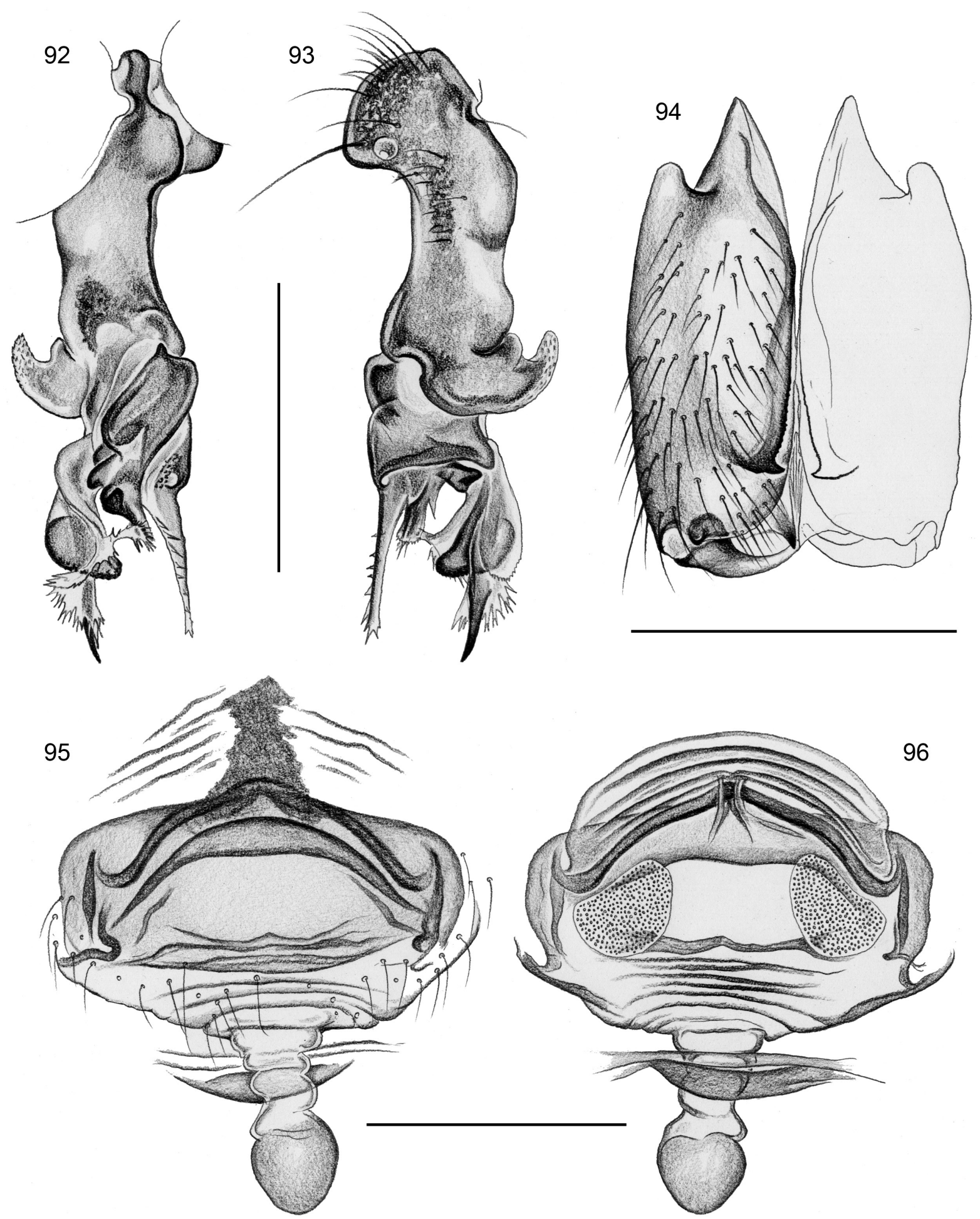

Figs 92-96. Spermophora maathaiae sp. nov. 92-93. Left $\widehat{\partial}$ procursus, prolateral and retrolateral views. 94. $\sigma^{7}$ chelicerae, frontal view. 95-96. 9 genitalia, ventral and cleared dorsal views. Scale lines: $0.5 \mathrm{~mm}$. 


\section{Type locality}

KENYA, Eastern Province, Mt. Kenya N.P., Chogoria Forest, “site 1" $\left(0^{\circ} 12.1^{\prime}\right.$ S, 37²9.4'E), $2460 \mathrm{~m}$ a.s.1., 27 Jan. 2010 (B.A. Huber).

\section{Other material examined}

KENYA: Eastern Province: 3 + 9,3 juvs. in pure ethanol, in ZFMK (Ken 112), Mt. Kenya N.P., Chogoria

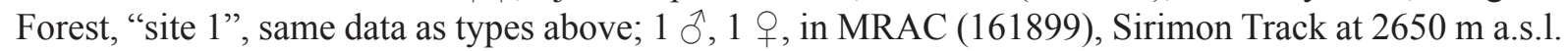
[003.8'S, 37'17.8'E], 24 Jul. 1975 (R. Bosmans). Central Province: 1 o in pure ethanol, in ZFMK (Ken 123), Mt. Kenya N.P., Naro Moru Forest, overhanging vegetation along road cut $\left(0^{\circ} 10.2^{\prime}-10.6^{\prime}\right.$ S,

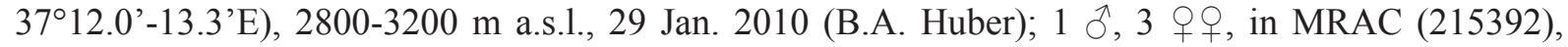
Castle Forest, bamboo forest at 2445 m a.s.1., 21 Apr. 2004 (R. Jocqué, C. Warui, van den Spiegel); 1 đ̂, in MRAC (215146), same data but ruins of old brick huts, $2370 \mathrm{~m}$ a.s.1..

\section{Description}

\section{Male (holotype)}

MEASUREMENTS. Total body length 3.2, carapace width 1.3. Leg 1: $20.8(5.2+0.5+5.3+7.2+2.6)$, tibia 2: 3.4, tibia 3: 2.6, tibia 4: 3.4; tibia $1 \mathrm{~L} / \mathrm{d}:$ 40. Distance PME-PME $240 \mu \mathrm{m}$, diameter PME $160 \mu \mathrm{m}$, distance PME-ALE $25 \mu \mathrm{m}$, no AME.

COLOR. Prosoma ochre-yellow with large lateral black marks, ocular area with black lateral marks, clypeus slightly darkened, sternum monochromous black, legs ochre-yellow, with darker rings on femora (subdistally) and tibiae (proximally, subdistally), abdomen grey with distinctive black pattern dorsally and laterally, ventrally mostly black.

BoDy. Habitus as in Fig. 46; ocular area elevated, with pair of horns in front of PME (similar S. mau, cf. Fig. 44, but wider apart); carapace only anteriorly with shallow thoracic furrow; clypeus unmodified. Chelicerae as in Fig. 94, frontal apophyses without modified hairs. Sternum wider than long (0.90/0.75), unmodified.

PALPS. In general as in $S$. mau sp. nov. (cf. Figs 87, 88); coxa with retrolatero-ventral apophysis, trochanter with retrolateral apophysis, femur barely modified (except dorsal apophysis proximally), procursus with ventral flap and several complex distal elements that appear hinged to proximal part (Figs 92, 93), bulb similar S. berlandi Fage, 1936 (cf. figs 262-263 in Huber 2003b), with two coneshaped projections and long embolus.

LEGS. Without spines and curved hairs, few vertical hairs; retrolateral trichobothrium on tibia 1 at $12 \%$; prolateral trichobothrium absent on tibia 1, present on other tibiae; tarsus 1 with $>20$ pseudosegments, distinct distally.

VARIATION. Tibia 1 in 5 other males: 5.1-5.6 (mean 5.5).

\section{Female}

In general similar to male but triads closer together (distance PME-PME $160 \mu \mathrm{m}$ ), without horns. Tibia 1 in 13 females: 4.1-4.8 (mean 4.4). Epigynum a simple plate with long posterior scape ending in wide rounded tip (Figs 66, 95); internal genitalia as in Figs 67 and 96.

\section{Distribution}

Known from Mount Kenya only (Fig. 27). 


\section{Spermophora bukusu sp. nov. urn:1sid:zoobank.org:act:79B65098-2BC0-4922-A582-9669C9FB099F}

Figs 45, 47-49, 68, 97-101

Spermophora Kenya 45: Dimitrov, Astrin \& Huber 2012 (DNA sequence data).

\section{Diagnosis}

Distinguished from the similar S. minotaura Berland, 1920 by male clypeus modification (without sclerotized elements projecting below eye triads), cheliceral armature (distal apophyses with simple rows of cone-shaped modified hairs; Fig. 99), details of male procursus and bulb (shapes of ventral 'flap'; distal procursus elements; embolus; Figs 97, 98), and female genitalia (triangular scape; absence of abdominal modification behind epigynum; Figs 68, 100). Easily distinguished from similar species with horns between eye triads (S. mau sp. nov.; S. berlandi Fage, 1936; S. maathaiae sp. nov.) by general shapes of procursus, bulb, and epigynum.

\section{Etymology}

The species is named after the Bukusu, a Kenyan tribe located mainly on the foothills of Mount Elgon; noun in apposition.

\section{Type material}

\section{Holotype}

$\hat{0}$, in ZFMK (Ar 8751).

\section{Paratypes}

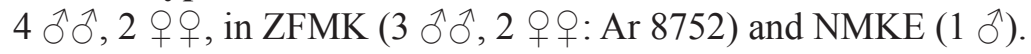

\section{Type locality}

KENYA, Rift Valley, Mt. Elgon N.P., along Kimothon River (104.6’'N, 3443.5’'E), 2510 m a.s.1., 31 Jan. 2010 (B.A. Huber).

\section{Other material examined}

KENYA: Rift Valley: $2 \widehat{\widehat{\partial}}, 2$ 우, 2 juvs. in pure ethanol, in ZFMK (Ken 133), Mt. Elgon N.P., along Kimothon River, same data as types above; $3 \hat{\jmath} \hat{\jmath}^{\lambda}, 2$ 우, in ZFMK (Ar 8753), Kitale Museum Forest $\left(\sim 1^{\circ} 01.3^{\prime} \mathrm{N}, 34^{\circ} 59.7^{\prime} \mathrm{E}\right), 1880 \mathrm{~m}$ a.s.1., 2 Feb. 2010 (B.A. Huber); 1 ', 4 우, 1 juv. in pure ethanol, in ZFMK (Ken 144), same data; 1 §’, 1 क , in ZFMK (Ar 8754), Mt. Elgon N.P., Kitum Cave $\left(1^{\circ} 01.8^{\prime} \mathrm{N}\right.$, $\left.34^{\circ} 45.4^{\prime} \mathrm{E}\right), 2410 \mathrm{~m}$ a.s.1., in forest outside cave, 31 Jan. 2010 (B.A. Huber). Western Province: 1 ㅇ, in ZFMK (Ar 8755), Mt. Elgon N.P., forest fragment ( $\left.1^{\circ} 04.3^{\prime} \mathrm{N}, 34^{\circ} 40.2^{\prime} \mathrm{E}\right), 3070 \mathrm{~m}$ a.s.1., 1 Feb. 2010 (B.A. Huber). UGANDA: Eastern Region: 2 ํํ수, 29 우 (6 vials), in ZFMK (Ar 8756-61), Mt. Elgon (Dist. Mbale) (1¹0’N, 34²6’E), 2900 m a.s.l., fogging of Ilex mitis, Sep. 1999 (T. Wagner).

\section{Description}

Male (holotype)

MEASUREMENTS. Total body length 3.2, carapace width 1.3. Leg 1: $22.6(5.8+0.4+5.9+7.9+2.6)$, tibia 2: 3.5, tibia 3: 2.7, tibia 4: 3.5; tibia $1 \mathrm{~L} / \mathrm{d}:$ 49. Distance PME-PME $205 \mu \mathrm{m}$, diameter PME $125 \mu \mathrm{m}$, distance PME-ALE $45 \mu \mathrm{m}$, no AME.

CoLor. Prosoma ochre-yellow with large lateral black marks and Y-mark behind ocular area, ocular area laterally darkened, sternum monochromous black, legs ochre-yellow, with darker rings on femora (subdistally) and tibiae (proximally, subdistally), abdomen grey with distinct black pattern, also ventrally. 


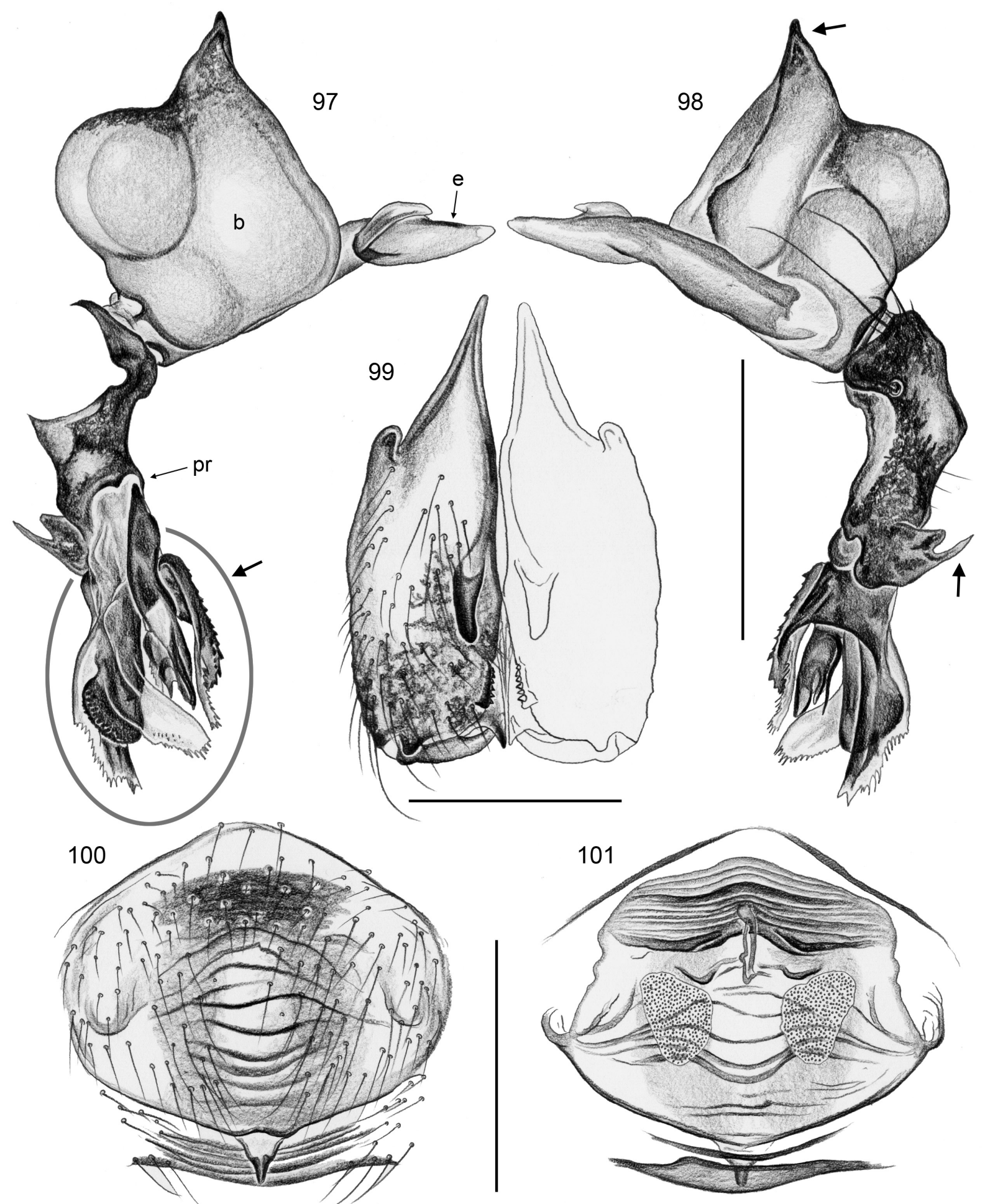

Figs 97-101. Spermophora bukusu sp. nov. 97-98. Left $\hat{\partial}$ procursus and bulb, prolateral and retrolateral views (arrows point to variable structures; see text). 99. $\delta^{\lambda}$ chelicerae, frontal view. 100-101. $q$ genitalia, ventral and cleared dorsal views. b: genital bulb; e: embolus; pr: procursus. Scale lines: $0.3 \mathrm{~mm}(99)$, $0.5 \mathrm{~mm}(97-98,100-101)$. 
Body. Habitus as in Figs 47-49; ocular area elevated, with pair of horns between triads (Fig. 45); carapace only anteriorly with shallow thoracic furrow, clypeus barely modified, only large membranous area that appears collapsed (in all males examined). Chelicerae as in Fig. 99, each distal frontal apophysis with straight row of six cone-shaped modified hairs, proximal frontal apophyses slightly flattened (more slender in lateral view). Sternum wider than long (0.86/0.70), unmodified.

PALPS. In general very similar S. minotaura Berland, 1920 (cf. figs 268 and 269 in Huber 2003a) but embolus distal elements different shape, procursus ventral 'flap' and distal elements also distinctive (Figs 97, 98).

LEGs. Without spines and curved hairs, few vertical hairs; retrolateral trichobothrium on tibia 1 at 9\%; prolateral trichobothrium absent on tibia 1, present on other tibiae; tarsus 1 with $>30$ pseudosegments, distinct distally.

VARIATIOn. Tibia 1 in 8 other males: 4.3-6.1 (mean 5.1). Males from Kitum Cave and from Kitale differ slightly in several respects (arrows in Figs 97 and 98): pointed process on ventral flap of procursus larger and more curved; shapes of distal procursus structures slightly different; bulbal pointed process slightly longer and more curved.

\section{Female}

In general similar to male but triads slightly closer together (distance PME-PME $170 \mu \mathrm{m}$ ), without horns. Tibia 1 in 4 females: 4.1, 4.2, 4.7, 4.9. Epigynum a simple protruding plate with strong transversal ridges, small posterior triangular scape, posteriorly some transversal ridges but no median modification (Figs 68, 100); internal genitalia as in Fig. 101.

\section{Distribution}

Known from Mt. Elgon area only (Kenya and Uganda) (Fig. 27).

Spermophora kirinyaga sp. nov. urn:Isid:zoobank.org:act:FB6D5694-B829-49B4-B47E-AAB80C170389

Figs 10, 50-52, 102-106

Spermophora Ken 21: Dimitrov, Astrin \& Huber 2012 (DNA sequence data).

\section{Diagnosis}

Easily distinguished from similar congeners (S. berlandi Fage, 1936, S. minotaura Berland, 1920) by absence of horns between eye triads; from $S$. berlandi Fage, 1936 also by absence of epigynal scape (only short conical projection; Fig. 105), from S. minotaura Berland, 1920 also by unmodified clypeus; from both and from other species also by details of male palp morphology (shapes of bulbal processes and procursus; Figs 102, 103) and male cheliceral armature (Fig. 104).

\section{Etymology}

Kirinyaga is a Kikuyu and Embu name for Mount Kenya; noun in apposition.

\section{Type material}

Holotype

○, in ZFMK (Ar 8762).

\section{Paratypes}

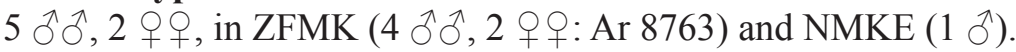




\section{Type locality}

KENYA, Eastern Province, Mt. Kenya National Park, Chogoria Forest, “site 2” ( $0^{\circ} 14.2^{\prime}$ S, 37 34.0'E), 1950 m a.s.l., under logs on ground, 27 Jan. 2010 (B.A. Huber).

\section{Other material examined}

KENYA: Eastern Province: 7 q 9,1 juv. in pure ethanol, in ZFMK (Ken 119), Mt. Kenya N.P., Chogoria Forest: same data as types above.

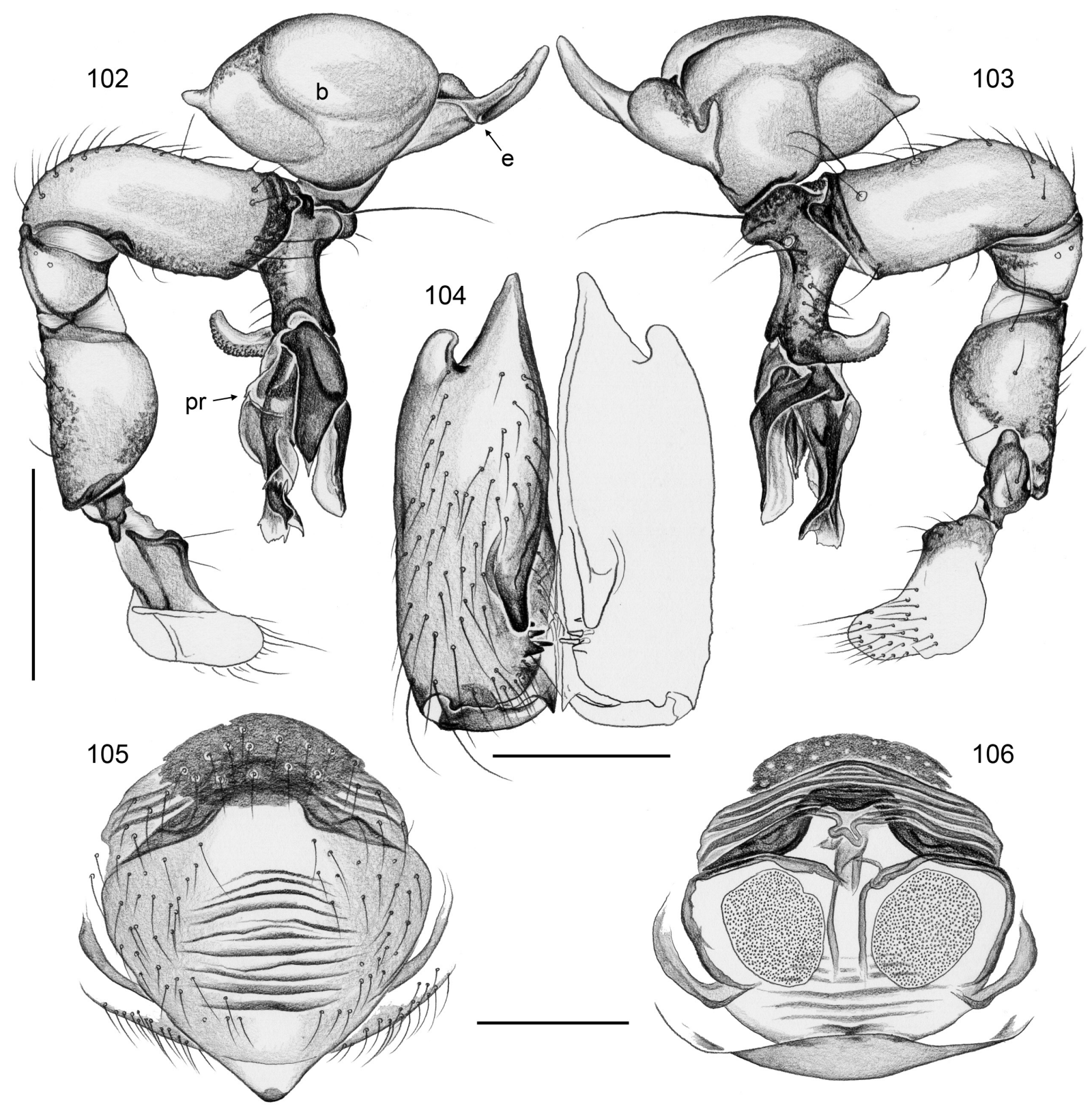

Figs 102-106. Spermophora kirinyaga sp. nov. 102-103. Left $ð$ palp, prolateral and retrolateral views. 104. $\widehat{o}$ chelicerae, frontal view. 105-106. $q$ genitalia, ventral and cleared dorsal views. b: genital bulb; e: embolus; pr: procursus. Scale lines: $0.2 \mathrm{~mm}$ (104), $0.3 \mathrm{~mm}$ (105-106), $0.5 \mathrm{~mm}$ (102-103). 


\section{Description}

Male (holotype)

MEAsurements. Total body length 2.2, carapace width 1.1. Leg 1: $17.1(4.2+0.4+4.3+6.2+2.0)$, tibia 2: 2.6, tibia 3: 2.0, tibia 4: 2.6; tibia $1 \mathrm{~L} / \mathrm{d}$ : 46. Distance PME-PME $205 \mu \mathrm{m}$, diameter PME $90 \mu \mathrm{m}$, distance PME-ALE $25 \mu \mathrm{m}$, no AME.

Color. Prosoma ochre with extensive black pattern including ocular area and clypeus, sternum mostly black, medially dark brown, legs ochre-yellow, darker subdistal rings and lighter tips barely visible, abdomen ochre-grey, largely covered with black marks, also ventrally.

BoDy. Habitus as in Fig. 50; ocular area slightly elevated, without horns; shallow but distinct thoracic furrow; clypeus unmodified. Chelicerae as in Fig. 104, with proximal lateral apophyses, large frontal apophyses (without modified hairs) and three long modified hairs on each side, the distal one accompanied by small black cone. Sternum wider than long $(0.72 / 0.64)$, unmodified.

PaLPS. As in Figs 102 and 103, coxa with retrolatero-ventral apophysis, trochanter with retrolateral apophysis, femur barely modified, procursus with ventral flap and several complex distal elements that appear hinged with proximal part, bulb with only one distally bifid process and small rounded projection on opposite side.

LEGS. Without spines and curved hairs, few vertical hairs; retrolateral trichobothrium on tibia 1 at $14 \%$; prolateral trichobothrium absent on tibia 1, present on other tibiae; tarsus 1 with $\sim 20$ pseudosegments.

VARIATION. Tibia 1 in 5 other males: 3.9-4.0.

\section{Female}

In general similar to male but triads closer together (distance PME-PME $135 \mu \mathrm{m}$ ). Tibia 1 in 2 females: 3.4, 3.5. Epigynum a large protruding plate with small projection posteriorly (Fig. 105); internal genitalia as in Fig. 106.

\section{Distribution}

Known from type locality only (Fig. 27).

Spermophora kyambura sp. nov. urn:1sid:zoobank.org:act:62CDAD37-6334-4C5F-AE18-EAF1F8F21D8F

Figs $57-58,69,107-110$

Spermophora Uga 31: Dimitrov, Astrin \& Huber 2012 (DNA sequence data). Spermophora Cam 64: Dimitrov, Astrin \& Huber 2012 (DNA sequence data).

\section{Diagnosis}

Tiny monochromous species, distinguished from superficially similar African species (Nyikoa limbe Huber, 2007, some 'Spermophora' and Quamtana species) by shape of simple short procursus (Fig. 108), simple bulbal apophysis and embolus with slightly sclerotized distal projection (Fig. 107), by shape of male cheliceral apophyses (provided with one modified hair each; Fig. 109), and by sac-like internal structure frontally in female genitalia (Figs 69, 110; usually visible through cuticle).

\section{Etymology}

The species name is derived from the type locality; noun in apposition. 


\section{Type material}

\section{Holotype}

$\widehat{0}$, in ZFMK (Ar 8764).

\section{Paratypes}

4 ठํํ, 11 우우, in ZFMK (Ar 8765).

\section{Type locality}

UGANDA, Bushenyi District, Kyambura River Gorge ( $\left.0^{\circ} 10.7^{\prime} \mathrm{S}, 30^{\circ} 05.8^{\prime} \mathrm{E}\right), 900 \mathrm{~m}$ a.s.1., 29 Nov. 2010 (B.A. Huber).

\section{Other material examined}

UGANDA: Western Region: 1 ð, 1 \& in pure ethanol, in ZFMK (Uga 140), Bushenyi District, Kyambura

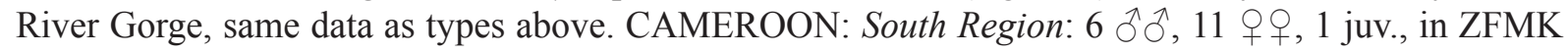
(Ar 8766), near Ebolowa ( $\left.2^{\circ} 54.9^{\prime} \mathrm{N}, 11^{\circ} 08.3^{\prime} \mathrm{E}\right), 620 \mathrm{~m}$ a.s.1., underside of banana leaves, $11-12 \mathrm{Apr}$. 2009 (B.A. \& J.C. Huber); 3 $\widehat{\jmath}, 9$ 우, 2 juvs. in pure ethanol, in ZFMK (Cam 102), same data.

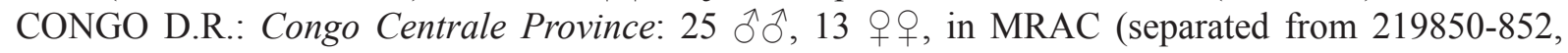

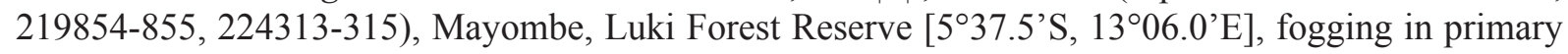
rainforest, 4-5, 7, 12-13 Nov. 2006, 27-29 Sep. 2007 (8 vials) (D. de Bakker, Michiels); 6 §ै ô, 10 우, in MRAC (separated from 224303, 309), same data but fogging in old secondary rainforest, 17 \& 23 Sep. 2007. Mongala Province: 5 o $^{\top}{ }^{\top}, 16$ 우 (3 vials), in MRAC, Mbangi ( $\left.2^{\circ} 07^{\prime} \mathrm{N}, 21^{\circ} 44^{\prime} \mathrm{E}\right)$, fogging, 23-24

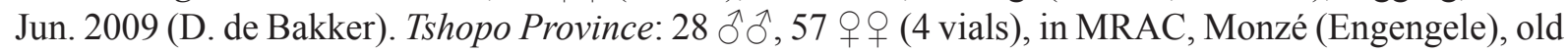
secondary forest, periodically inundated ( $\left.2^{\circ} 02^{\prime} \mathrm{N}, 22^{\circ} 44^{\prime} \mathrm{E}\right)$, fogging, 29-30 Jun. 2009 (D. de Bakker);

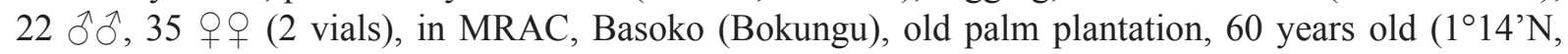
233'ㄹ), fogging, 7 Mar. 2009 (D. de Bakker).

\section{Material assigned tentatively}

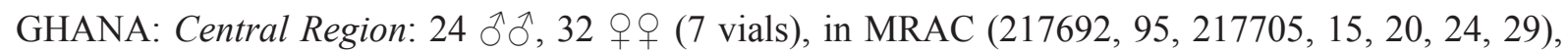
Kakum forest $\left(5^{\circ} 20^{\prime} \mathrm{N}, 1^{\circ} 23^{\prime} \mathrm{W}\right)$, fogging in primary and secondary forest, 14-19 \& 25 Nov. 2005 (R. Jocqué, D. de Bakker, L. Baert).

\section{Description}

\section{Male (holotype)}

Measurements. Total body length 1.35, carapace width 1.0. Leg 1: $7.8(2.0+0.2+2.1+2.6+0.9)$, tibia 2: 1.4, tibia 3: 0.9, tibia 4: 1.2; tibia $1 \mathrm{~L} / \mathrm{d}$ : 43. Distance PME-PME $90 \mu \mathrm{m}$, diameter PME $70 \mu \mathrm{m}$, distance PME-ALE $10 \mu \mathrm{m}$, no AME.

Color. Prosoma monochromous pale ochre-yellow, legs ochre yellow, without darker rings, abdomen monochromous pale grey.

Body. Habitus as in Figs 57 and 58; ocular area barely elevated, carapace without thoracic furrow; clypeus unmodified. Chelicerae as in Fig. 109, each distal frontal apophysis with one modified hair at tip. Sternum wider than long $(0.65 / 0.55)$, unmodified.

PALPS. As in Figs 107 and 108, coxa with small ventral apophysis, trochanter with retrolateral apophysis (slightly longer than appears in Fig. 108), procursus very simple, without hinged process, without ventral flap; bulb with large proximal sclerite, small rectangular apophysis, embolus with slightly sclerotized distal projection. 


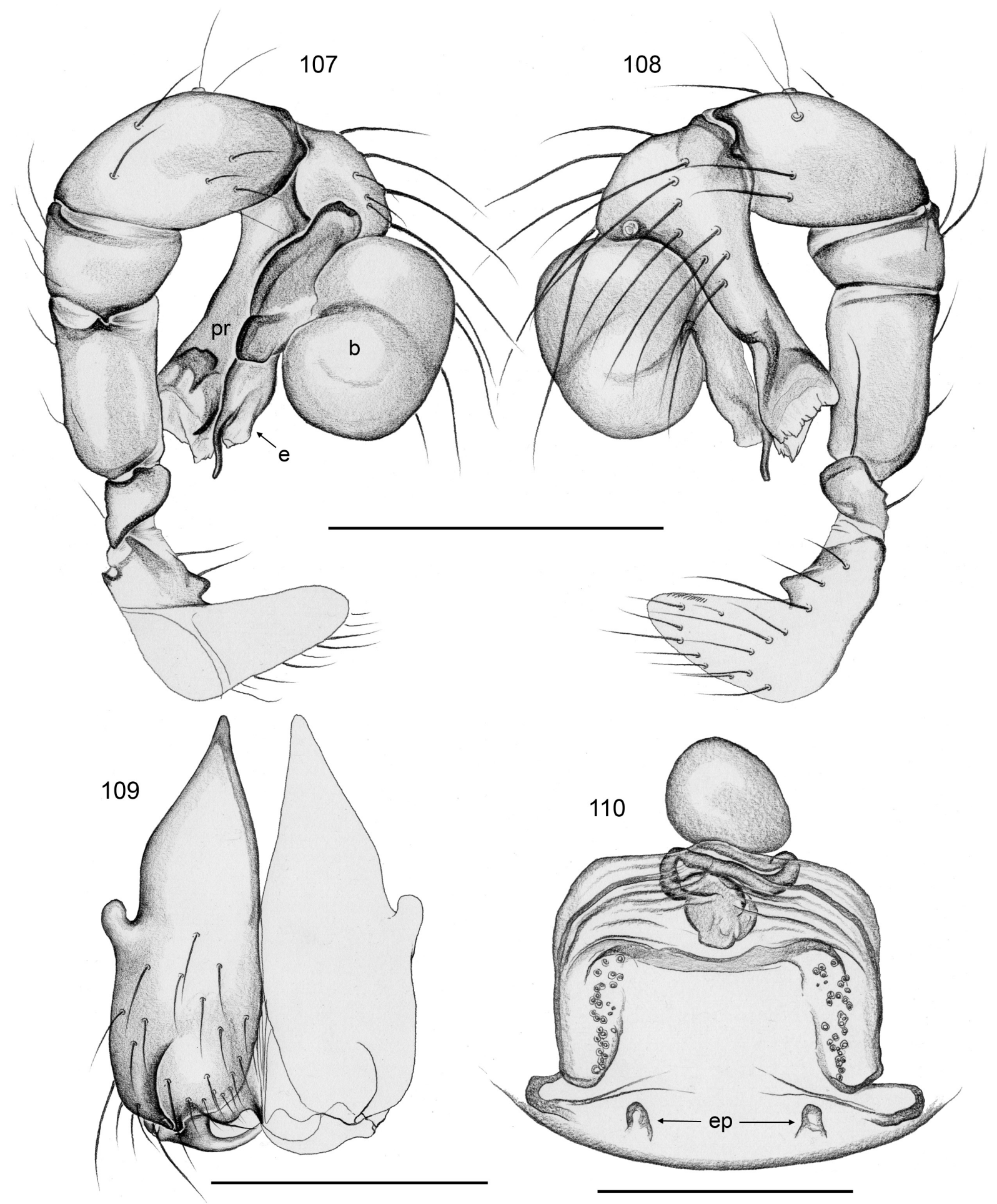

Figs 107-110. Spermophora kyambura sp. nov. 107-108. Left $ð$ palp, prolateral and retrolateral views. 109. $\widehat{o}$ chelicerae, frontal view. 110. $q$ genitalia, cleared dorsal view. b: genital bulb; e: embolus; ep: epigynal pockets; pr: procursus. Scale lines: $0.2 \mathrm{~mm}$ (109-110), $0.3 \mathrm{~mm}$ (107-108). 
LEGS. Without spines and curved hairs, few vertical hairs; retrolateral trichobothrium on tibia 1 at $21 \%$; prolateral trichobothrium absent on tibia 1, present on other tibiae; tarsus 1 with $\sim 20$ pseudosegments, distinct distally.

VARIATION. Tibia 1 in 22 other males from Uganda, Congo DR and Cameroon: 2.3-2.6 (mean 2.4). Males from Ghana seem to have indistinguishable palps but slightly longer and more widely spaced cheliceral apophyses and slightly shorter legs: tibia 1 in 21 males from Ghana: 2.0-2.3 (mean 2.1); they are therefore assigned tentatively.

\section{Female}

In general similar to male. Tibia 1 in 34 females from Uganda, Congo DR and Cameroon: 1.6-2.0 (mean 1.8). Epigynum extremely simple, no external modification visible in dissecting microscope; only internal frontal sac-like structure visible through cuticle; pair of pockets only visible in compound microscope (Fig. 110). In females from Ghana, these pockets are barely visible and slightly wider apart; tibia 1 in 20 females from Ghana: 1.4-1.6 (mean 1.55).

\section{Distribution}

Widely distributed in tropical Africa (Uganda, Congo DR, Cameroon; possibly also Ghana). Figure 27 shows the only record from East Africa.

Quamtana nyahururu sp. nov.

urn:1sid:zoobank.org:act:CE25DF38-4C5F-4638-98C4-0AA71A061B70

Figs 6, 59-61, 111-115

Quamtana Kenya 10: Dimitrov, Astrin \& Huber 2012 (DNA sequence data).

\section{Diagnosis}

Distinguished from known congeners by combination of male cheliceral armature (Fig. 113), male palp (shapes of procursus and bulbal process; Figs 111, 112), and absence of AME. The South African Quamtana ciliata (Lawrence, 1938) and Q. mbaba Huber, 2003 are similar but both have AME and are much larger (total body length $\sim 3.0$ ).

\section{Etymology}

The species name is derived from the type locality; noun in apposition.

\section{Type material}

\section{Holotype}

ô, in ZFMK (Ar 8767).

\section{Paratypes}

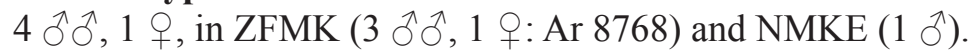

\section{Type locality}

KENYA, Rift Valley Province, Thompson Falls near Nyahururu ( $\left.0^{\circ} 02.7^{\prime} \mathrm{N}, 36^{\circ} 22.1^{\prime} \mathrm{E}\right), 2350 \mathrm{~m}$ a.s.1., on underside of leaf, 30 Jan. 2010 (B.A. Huber).

\section{Other material examined}

KENYA: Rift Valley Province: 1 + 2 juvs. in pure ethanol, in ZFMK (Ken 132), Thompson Falls near

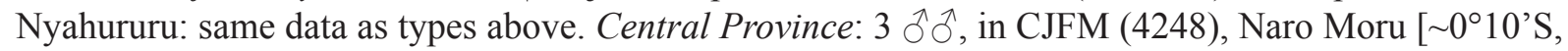




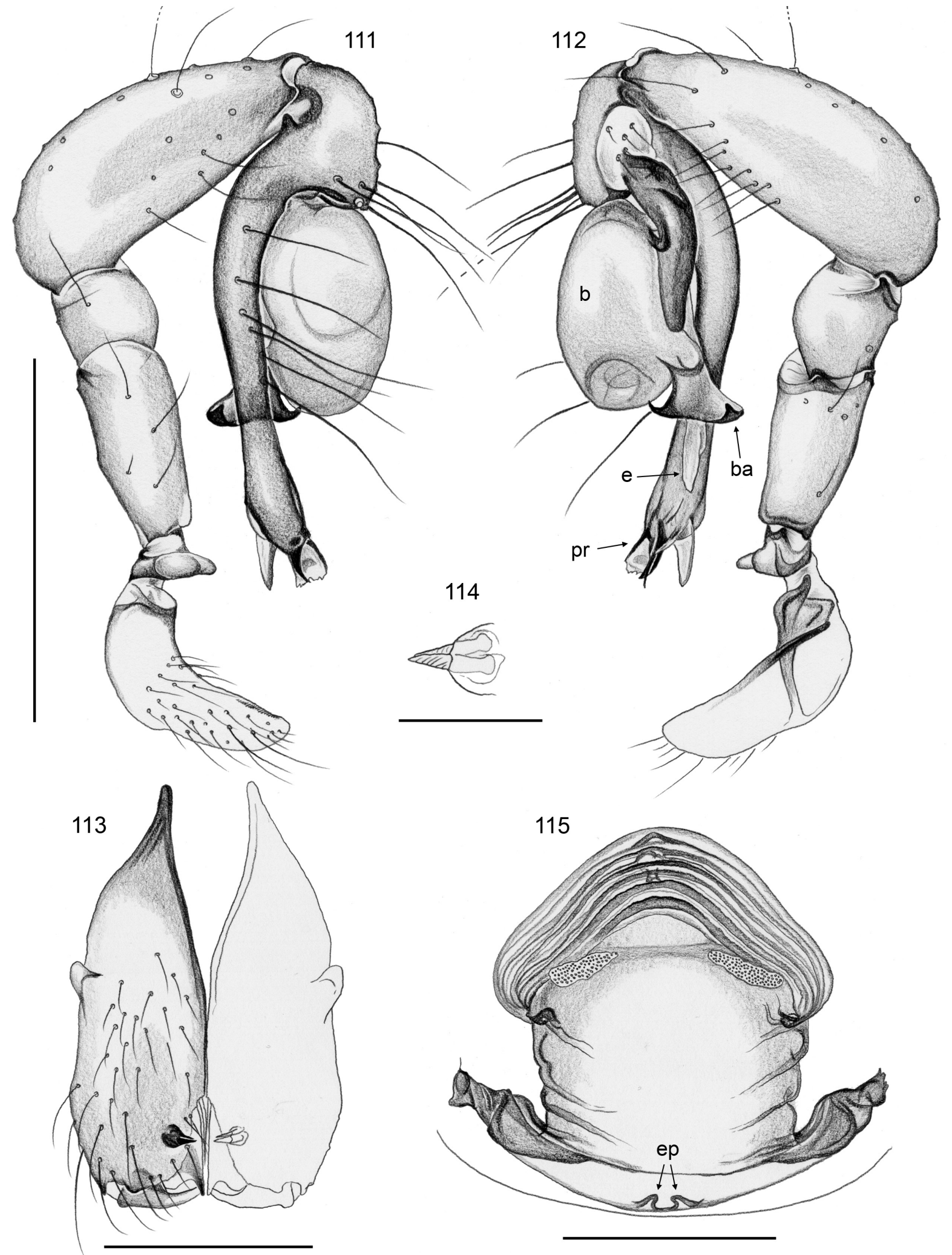

Figs 111-115. Quamtana nyahururu sp. nov. 111-112. Right $\widehat{\delta}$ palp, retrolateral and prolateral views.

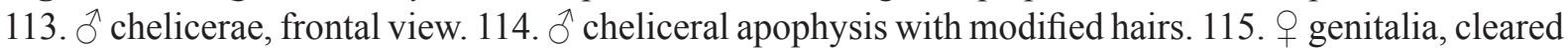
dorsal view. b: genital bulb; ba: bulbal apophysis; e: embolus; ep: epigynal pockets; pr: procursus. Scale lines: $0.05 \mathrm{~mm}(114), 0.2 \mathrm{~mm}(113,115), 0.5 \mathrm{~mm}(111-112)$. 
3702'E], 2000 m a.s.l., riverside scrub, 17 Aug. 1974 (Murphy); 1 §, in ZFMK (Ar 8718), Kikuyu Escarpment, Gatamaiyu ( $\left.0^{\circ} 58^{\prime} \mathrm{S}, 36^{\circ} 42^{\prime} \mathrm{E}\right), 2330 \mathrm{~m}$ a.s.1., mountain forest, fogging of Podocarpus latifolius, Feb. 1999 (T. Wagner). Nairobi Area: 6 추, 2 우, in CJFM (3540, 6635), Nairobi, Muthaiga Golf Club rough [1 ${ }^{\circ} 15^{\prime}$ S, 36 50'E], 1600 m a.s.l., 15 Jul. 1974 and 26 Sep. 1977 (2 vials) (Murphy).

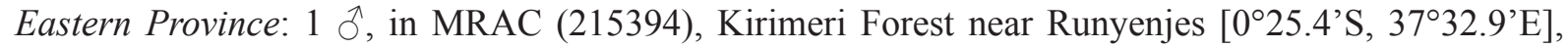

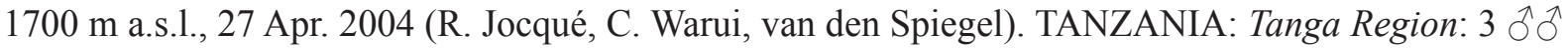
(3 vials), in ZMUC, Lushoto Dist., Mazumbai Forest Reserve (4'49'S, 38²9'S), 1650-1730 m a.s.1., 22 Nov. 1995 (ZMUC Expedition), "Fog 25-BO", "Fog 25-FL", "Fog 25-EJ"; 1 ○े, in ZMUC, same locality, date not given, "Fog 4-DF"; 1 क in ZMUC, Mazumbai Forest Reserve at 449'S, 38 31'E, 1370-1435 m a.s.1., 4 Oct. 1995, "Fog 31-DO".

\section{Description}

Male (holotype)

MeAsuRements. Total body length 1.6, carapace width 0.65 . Leg 1: $13.0(3.3+0.3+3.5+4.8+1.1)$, tibia 2: 2.0, tibia 3 missing, tibia 4: 2.0; tibia $1 \mathrm{~L} / \mathrm{d}$ : 56. Distance PME-PME $175 \mu \mathrm{m}$, diameter PME 70 $\mu \mathrm{m}$, distance PME-ALE $20 \mu \mathrm{m}$, no trace of AME.

CoLor. Prosoma pale whitish with wide dark median band on carapace including clypeus but not ocular area, legs pale ochre-yellow, without darker rings, abdomen monochromous pale grey.

Body. Habitus as in Figs 59 and 60; ocular area barely elevated, each triad on low hump; no thoracic furrow; clypeus unmodified. Chelicerae as in Fig. 113, with proximal lateral apophyses and distal frontal apophyses provided with two long modified hairs each (Fig. 114), without stridulatory ridges. Sternum wider than long $(0.48 / 0.40)$, unmodified.

PALPS. As in Figs 111 and 112, coxa unmodified, trochanter with short retrolatero-ventral apophysis, femur barely modified, procursus simple except distally, bulb with T-shaped process and transparent straight embolus arising from bulb next to T-shaped process.

LEGS. Without spines and curved hairs, few vertical hairs (most hairs missing); retrolateral trichobothrium on tibia 1 at $9 \%$; prolateral trichobothrium absent on tibia 1, present on other tibiae; pseudosegments not visible in dissecting microscope.

VARIATION. Tibia 1 in 15 other males: 2.8-3.7 (mean 3.3). In most males, the bulb is rotated out from its normal position (cf. figs 79, 80, 107, 108 in Huber 2003b).

\section{Female}

In general similar to male but triads even less elevated and much closer together (distance PME-PME $105 \mu \mathrm{m}$ ). Tibia 1 in 5 females: 2.3-2.5. Epigynum extremely simple externally, unsclerotized (Fig. 61) with pair of tiny pockets near posterior rim; internal genitalia as in Fig. 115.

\section{Distribution}

Known from several localities in Kenya and Tanzania (Fig. 25).

\section{Acknowledgements}

BAH thanks the many people who kindly sent specimens used in this study: J. Beccaloni, C.E. Griswold, R. Jocqué, E.-A. Leguin, L. Leibensperger, J. Murphy, C. Rollard, A. Russell-Smith, M. Saaristo, N. Scharff, and S. Whitman. We thank G. Eilu for help in acquiring collection and export permits in Uganda and A. Kushemererwa and R. Mwakodi for assistance during the collecting trips in Uganda and Kenya respectively. We thank H. Krammer for help during the initial phase of this project, and S. Bayer and an 
anonymous reviewer for many helpful comments on a previous version of the manuscript. The German Research Foundation provided financial support (DFG, HU 980/9-1).

\section{References}

Berland L. 1919. Diagnoses préliminaires d'Araignées d'Afrique orientale. Voyage de Ch. Alluaud et R. Jeannel. Annales de la Société Entomologique de France (1919): 347-350.

Berland L. 1920. Voyage de Ch. Alluaud et R. Jeannel en Afrique Orientale (1911-1912). Araneae (2e partie). Libraire des Sciences Naturelles, Paris.

Caporiacco L. di. 1941. Arachnida. Missione Biologica Sagan-Omo, Vol. 12 (Zoologia, 6). Reale Accademia d'Italia, Rome.

Deeleman-Reinhold C.L. \& Prinsen J.D. 1987. Micropholcus fauroti (Simon) n. comb., a pantropical, synanthropic spider (Araneae: Pholcidae). Entomologische Berichten 47 (5): 73-77.

Deeleman-Reinhold, C.L. \& van Harten, A. 2001. Description of some interesting, new or little known Pholcidae (Araneae) from Yemen. In: Ishwar Prakash (ed.) Ecology of Desert Environments: 193-207. Scientific Publishers, Jodhpur (India).

Dimitrov D., Astrin J.J. \& Huber B.A. 2012. Pholcid spider molecular systematics revisited, with new insights into the biogeography and the evolution of the group. Cladistics (in press). http://dx.doi. org/10.1111/j.1096-0031.2012.00419.x

Fage L. \& Simon E. 1936. Arachnida. III. Pedipalpi, Scorpiones, Solifuga et Araneae (1re partie). Mission scientifique de l'Omo 3 (30): 293-340.

Huber B.A. 1996. On the distinction between Modisimus and Hedypsilus (Pholcidae; Araneae), with notes on behavior and natural history. Zoologica Scripta 25: 233-240.

Huber B.A. 2000. New World pholcid spiders (Araneae: Pholcidae): a revision at generic level. Bulletin of the American Museum of Natural History 254: 1-348. http://dx.doi.org/10.1206/00030090(2000)254<0001:NWPSAP $>2.0 . \mathrm{CO} ; 2$

Huber B.A. 2003a. High species diversity in one of the dominant groups of spiders in East African montane forests (Araneae: Pholcidae: Buitinga n. gen., Spermophora Hentz). Zoological Journal of the Linnean Society 137: 555-619. http://dx.doi.org/10.1046/j.1096-3642.2003.00053.x

Huber B.A. 2003b. Southern African pholcid spiders: revision and cladistic analysis of Quamtana n. gen. and Spermophora Hentz (Araneae: Pholcidae), with notes on male-female covariation. Zoological Journal of the Linnean Society 139: 477-527. http://dx.doi.org/10.1046/j.0024-4082.2003.00082.x

Huber B.A. 2005. Revision of the genus Spermophora Hentz in Southeast Asia and on the Pacific Islands, with descriptions of three new genera (Araneae: Pholcidae). Zoologische Mededelingen 79-2 (4): 61-172.

Huber B.A. 2007. Two new genera of small, six-eyed pholcid spiders from West Africa, and first record of Spermophorides for mainland Africa (Araneae: Pholcidae). Zootaxa 1635: 23-43.

Huber B.A. 2009. Life on leaves: leaf-dwelling pholcids of Guinea, with emphasis on Crossopriza cylindrogaster, a spider with inverted resting position, pseudo-eyes, lampshade web, and tetrahedral egg-sac (Araneae: Pholcidae). Journal of Natural History 43: 2491-2523. http://dx.doi. org/10.1080/00222930903207876

Huber B.A. 2011. Revision and cladistic analysis of Pholcus and closely related taxa (Araneae, Pholcidae). Bonner zoologische Monographien 58: 1-509. 
Huber B.A. 2012. Revision and cladistic analysis of the Afrotropical endemic genus Smeringopus Simon, 1890 (Araneae: Pholcidae). Zootaxa 3461: 1-138.

Huber B.A. \& El Hennawy H. 2007. On Old World ninetine spiders (Araneae: Pholcidae), with a new genus and species and the first record for Madagascar. Zootaxa 1635: 45-53.

Indeje M., Semazzi F.H.M. \& Ogallo L.J. 2000. ENSO signals in East African rainfall seasons. International Journal of Climatology 20: 19-46. http://dx.doi.org/10.1002/(SICI)10970088(200001)20:1<19::AID-JOC449>3.0.CO;2-0

Kraus O. 1957. Araneenstudien 1. Pholcidae (Smeringopodinae, Ninetinae). Senckenbergiana biologica 38 (3/4): 217-243.

Lawrence R.F. 1938. A collection of spiders from Natal and Zululand. Annals of the Natal Museum 8 (3): 455-524.

Lessert R. de. 1915. Arachnides de l'Ouganda et de l'Afrique orientale allemande. Revue suisse de Zoologie 23: 1-80.

Linder H.P., Klerk H.M. de, Born J., Burgess N.D., Fjeldså J. \& Rahbeck C. 2012. The partitioning of Africa: statistically defined biogeographical regions in sub-Saharan Africa. Journal of Biogeography 39: 1189-1205. http://dx.doi.org/10.1111/j.1365-2699.2012.02728.x

Saaristo M.I. 2001. Pholcid spiders of the granitic Seychelles (Araneae, Pholcidae). Phelsuma 9: 9-28.

Shongwe M.E., van Oldenborgh G.J., van den Hurk B. \& van Aalst M. 2011. Projected changes in mean and extreme precipitation in Africa under global warming. Part II: East Africa. Journal of Climate 24, 3718-3733. http://dx.doi.org/10.1175/2010JCLI2883.1

Simon E. \& Fage L. 1922. Araneae des grottes de l'Afrique orientale. In Biospeologica, XLIV. Archives de zoologie expérimentale et générale 60: 523-555.

Sørensen L.L. 2003. Stratification of the spider fauna in a Tanzanian forest. In: Basset Y., Novotny V., Miller S. \& Kitching R. (eds) Arthropods of Tropical Forests: Spatio-Temporal Dynamics and Resource Use in the Canopy: 92-101. Cambridge University Press, Cambridge.

Sørensen L.L., Coddington J.A. \& Scharff N. 2002. Inventorying and estimating spider diversity using semi-quantitative sampling methods in an afrotropical montane forest. Environmental Entomology 31: 319-330.

Strand E. 1906a. Diagnosen nordafrikanischer, hauptsächlich von Carlo Freiherr von Erlanger gesammelter Spinnen. Zoologischer Anzeiger 30: 655-690.

Strand E. 1906b. Tropischafrikanische Spinnen des kgl. Naturalienkabinetts in Stuttgart. Jahreshefte des Vereins für vaterländische Naturkunde in Württemberg 62: 13-103.

Strand E. 1907. Vorläufige Diagnosen afrikanischer und südamerikanischer Spinnen. Zoologischer Anzeiger 31: 525-558.

Strand E. 1913. Arachnida. I. Wissenschaftliche Ergebnisse der Deutschen Zentral-Afrika-Expedition 1907-1908, 4 (Zoologie II): 325-474. Leipzig.

Tullgren A. 1910. Araneae. Wissenschaftliche Ergebnisse der schwedischen zoologischen Expedition nach dem Kilimandjaro, dem Meru und den umgebenden Massaisteppen Deutsch-Ostafrikas 3: 86-172. Stockholm.

Wunderlich J. 1992. Die Spinnen-Fauna der Makaronesischen Inseln. Taxonomie, Ökologie, Biogeographie und Evolution. Beiträge zur Araneologie 1: 1-619. 
Manuscript received: 20 September 2012

Manuscript accepted: 29 October 2012

Published on: 26 November 2012

Topic editor: Rudy Jocqué

Printed versions of all papers are also deposited in the libraries of the institutes that are members of the EJT consortium: Muséum National d'Histoire Naturelle, Paris, France; National Botanic Garden of Belgium, Meise, Belgium; Royal Museum for Central Africa, Tervuren, Belgium; Natural History Museum, London, United Kingdom; Royal Belgian Institute of Natural Sciences, Brussels, Belgium; Natural History Museum of Denmark, Copenhagen, Denmark. 